\title{
Inducible expression of beta defensins by human respiratory epithelial cells exposed to Aspergillus fumigatus organisms
} Ludmila Alekseeva1,2, Dominique Huet ${ }^{1}$, Françoise Féménia1, Isabelle Mouyna3 ${ }^{3}$, Mahdia Abdelouahab1, Adrien Cagna1, Daniel Guerrier ${ }^{4}$, Virginie Tichanné-Seltzer ${ }^{5}$, Armelle Baeza-Squiban ${ }^{5}$, René Chermette ${ }^{1,6}$, JeanPaul Latgé 3 and Nadia Berkova*1

Address: ${ }^{1}$ UMR 956, INRA, AFSSA, ENVA, 22 rue Curie, 94700 Maisons Alfort Cedex, France, ${ }^{2}$ Shemyakin and Ovchinnikov Institute of Bioorganic Chemistry, RAS; Moscow, Russian Federation, ${ }^{3}$ Unité des Aspergillus, Institut Pasteur, 75724 Paris, France, ${ }^{4}$ CNRS UMR 6061, Université de Rennes 1, 2 av. Pr. Léon Bernard, 35043 Rennes Cedex, France, 5 Laboratoire de Cytophysiologie et Toxicologie Cellulaire, Université Paris 7, 75251 Paris, France and ${ }^{6}$ Service de Parasitologie-Mycologie, Ecole Nationale Vétérinaire d'Alfort, 7 av. de Général de Gaulle, 94704 Maisons Alfort Cedex, France

Email: Ludmila Alekseeva - luda.alekseeva@mail.ru; Dominique Huet - dhuet@vet-alfort.fr; Françoise Féménia - ffemenia@vet-alfort.fr; Isabelle Mouyna - imouyna@pasteur.fr; Mahdia Abdelouahab - mabdelouahab@vet-alfort.fr; Adrien Cagna - acagna@vet-alfort.fr; Daniel Guerrier - daniel.guerrier@univ-rennes1.fr; Virginie Tichanné-Seltzer - tichanne-seltzer@univ-paris-diderot.fr; Armelle BaezaSquiban - baeza@univ-paris-diderot.fr; René Chermette - rchermette@vet-alfort.fr; Jean-Paul Latgé - jplatge@pasteur.fr;

Nadia Berkova* - nberkova@vet-alfort.fr

* Corresponding author

Published: II February 2009

BMC Microbiology 2009, 9:33 doi:10.1 186/1471-2180-9-33
Received: 29 July 2008

Accepted: II February 2009

This article is available from: http://www.biomedcentral.com/I47I-2/80/9/33

(C) 2009 Alekseeva et al; licensee BioMed Central Ltd.

This is an Open Access article distributed under the terms of the Creative Commons Attribution License (http://creativecommons.org/licenses/by/2.0), which permits unrestricted use, distribution, and reproduction in any medium, provided the original work is properly cited.

\begin{abstract}
Background: Aspergillus fumigatus, a saprophytic mould, is responsible for life-threatening, invasive pulmonary diseases in immunocompromised hosts. The role of the airway epithelium involves a complex interaction with the inhaled pathogen. Antimicrobial peptides with direct antifungal and chemotactic activities may boost antifungal immune response.

Results: The inducible expression of defensins by human bronchial epithelial I6HBE cells and A549 pneumocyte cells exposed to $A$. fumigatus was investigated. Using RT-PCR and real time PCR, we showed an activation of hBD2 and hBD9 defensin genes: the expression was higher in cells exposed to swollen conidia (SC), compared to resting conidia (RC) or hyphal fragments (HF). The kinetics of defensin expression was different for each one, evoking a putative distinct function for each investigated defensin. The decrease of defensin expression in the presence of heat-inactivated serum indicated a possible link between defensins and the proteins of the host complement system. The presence of defensin peptide hBD2 was revealed using immunofluorescence that showed a punctual cytoplasmic and perinuclear staining. Quantification of the cells stained with anti hBD2 antibody demonstrated that SC induced a greater number of cells that synthesized hBD2, compared to RC or HF. Labelling of the cells with anti-hBD-2 antibody showed a positive immunofluorescence signal around RC or SC in contrast to HF. This suggests co-localisation of hBD2 and digested conidia. The HBD2 level was highest in the supernatants of cells exposed to SC, as was determined by sandwich ELISA. Experiments using neutralising anti-interleukine-I $\beta$ antibody reflect the autocrine mechanism of defensin expression induced by SC. Investigation of defensin expression at transcriptional and post-transcriptional levels demonstrated the requirement of
\end{abstract}


transcription as well as new protein synthesis during $A$. fumigatus defensin induction. Finally, induced defensin expression in primary culture of human respiratory cells exposed to $A$. fumigatus points to the biological significance of described phenomena.

Conclusion: Our findings provide evidence that respiratory epithelium might play an important role in the immune response during Aspergillus infection. Understanding the mechanisms of regulation of defensin expression may thus lead to new approaches that could enhance expression of antimicrobial peptides for potential therapeutic use during aspergillosis treatment.

\section{Background}

Aspergillus fumigatus (A. fumigatus) is a saprophytic mould that is responsible for life-threatening invasive pulmonary diseases in immunocompromised hosts. In general, A. fumigatus is propagated through airborne conidia [1]. Despite the availability of new antifungal drugs, the number of deaths due to invasive aspergillosis has progressively increased in the last decades with a rise in the number of immunosuppressed patients in modern clinical practices [2]. Therefore, a better understanding of the mechanisms responsible for resistance to Aspergillus infection is required. The respiratory epithelium plays an important role in the innate immune defence against various inhaled pathogens by sensing the signal from the external environment and stimulating the synthesis of the antimicrobial molecules directly affecting the microbes [3]. The defensin family of antimicrobial peptides is an evolutionary conserved group of small cationic peptides involved in the innate immune system of plants and animals. They are divided into $\alpha-$, $\beta$ - and $\theta$-defensins, which differ from one another by the spacing and connectivity of their six cystein residues [4]. It was found that $\alpha$-defensins are generally stored in the azurophilic granules of neutrophils and Peneth cells of the small intestine [5]. Defensins isolated from rhesus monkey neutrophils are referred to as $\theta$-defensins because of their circular molecular structure [6]. Human $\beta$-defensins (hBD) are characteristic of epithelial tissue; they have been identified by traditional peptide purification, genomics-based searches [7-9] and an ORFeomebased peptide database search [10]. Some of these defensins are tissue-specific, whereas others are expressed in the epithelium of different origins: hBD1 is expressed in most epithelial cells $[11,12]$, while hBD2 is most commonly expressed in the lung and thymus $[13,14]$. Newly discovered defensin hBD9 was found to be ubiquitously expressed in most tissues [10]. Inducible hBD2 expression by the epithelial cells exposed to microbial pathogens is well documented [15]. The direct killing of microorganisms has been ascribed to human defensins [7]. It was recently recognised that defensins have additional activities such as the chemoattraction of immature dendritic cells, T cells and monocytes, as well as activation of the professional antigen-presenting cells
[16-18]. Killing of A. fumigatus by rabbit neutrophil cationic peptides [19], as well as antifungal activities of hBD2 against $A$. fumigatus [20], has been reported in in vitro experiments. Moreover, the expression of human drosomycin-like defensins, which display a broad spectrum of activity against Aspergillus spp, was found in several human tissues [21].

The role of the airway epithelium is not limited to the first mechanical barrier, but instead involves a complex interaction with A. fumigatus [22-24]. We hypothesized that various defensins may be expressed by the respiratory epithelium exposed to A. fumigatus. Taking the possibility into account that some host immunological reactions are A. fumigatus morphotype-specific $[25,26]$, the present study has been designed to investigate the expression of defensins by human pneumocytes and bronchial epithelial cells exposed to different forms of $A$. fumigatus: RC, SC or HF. The expression of previously studied hBD1 [4] and hBD2 [14,15], as well as recently discovered hBD8, hBD9 and hBD18 [10], were analysed. Since hBD2 and hBD9 were found to be highly expressed by cells exposed to A. fumigatus, those defensins were chosen for further analysis in the current study. The inducible expression of hBD2 and hBD9 was revealed by RT-PCR in airway epithelial cells exposed to A. fumigatus organisms. Real time PCR demonstrated that the expression was higher in cells exposed to SC, compared to RC or HF. The presence of the intracellular hBD2 peptide was demonstrated using immunofluorescence. The HBD2 level was highest in the supernatants of cells exposed to SC, as determined by sandwich ELISA. Furthermore, it was found that transcriptional and posttranscriptional mechanisms are involved in the regulation of defensin expression. Detection of inducible defensin expression in human airway primary culture epithelial cells was proof of the biological significance of obtained results. Our finding that hBD2 and hBD9 are expressed and produced (hBD2) in human respiratory epithelial cells exposed to A. fumigatus is novel and indicates that respiratory epithelium might play an important role in the early immune response during Aspergillus infection. 


\section{Results \\ Expression of defensins by human pneumocytes and bronchial epithelial cells exposed to $A$. fumigatus}

The expression of human defensins, hBD1 and hBD2, and newly described hBD8, hBD9 and hBD18, by the human pneumocytes A549 and bronchial epithelial cells 16HBE exposed to SC, RC or HF of A. fumigatus in the presence of Fetal Calf Serum was analysed by RT-PCR performed under the conditions presented in Table 1 . The powerful defensin inductor, Il-1 $\beta$, was used in experiments as a positive control. The cells were exposed either to $10^{6}$ of $A$. fumigatus conidia, $20 \mu \mathrm{l}$ of $A$. fumigatus HF solution, or 5 $\times 10^{6}$ latex beads for $18 \mathrm{~h}$. Compared to the control samples containing the untreated cells, an inducible expression of human beta defensins (hBD) 2, 8, 9 and 18 by $16 \mathrm{HBE}$ cells exposed to Il-1 $\beta$ was observed (Figure 1). Exposure of the cells to all of the morphotypes of A. fumigatus resulted in the strong inducible expression of hBD2

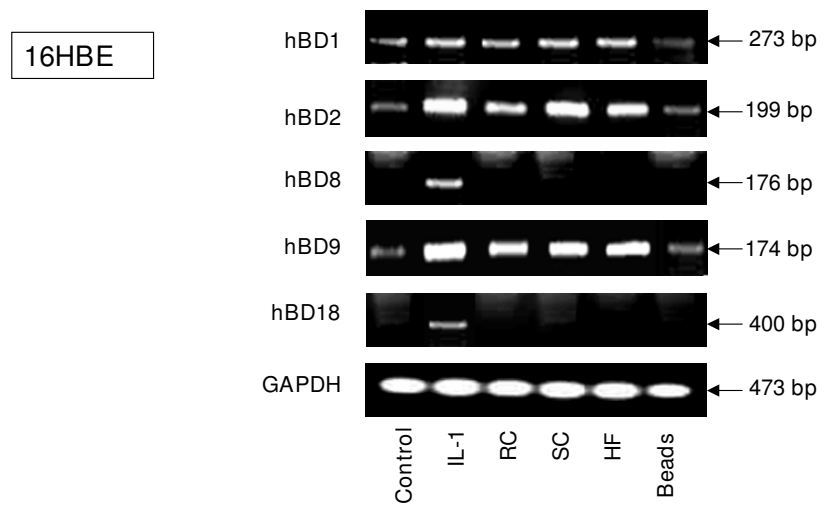

\section{Figure I}

RT-PCR analysis of various defensin expression levels in human I $6 \mathrm{HBE}$ epithelial bronchial cells exposed to A. fumigatus organisms. $16 \mathrm{HBE}$ human epithelial tracheal cells $\left(5 \times 10^{6}\right)$ were grown in six well plates for 24 hours. After exposing the cells to RC, SC, HF or latex beads for 18 hours, the cells were washed with PBS, mRNA was isolated by TRIzol Reagent and RT-PCR was performed as described above in Materials and Methods. Specific primer pairs (Table I) were used for RNA amplification: hBDI, 273 bp product; hBD2, 199 bp product; hBD8, I 76 bp product; hBD9, I 74 bp product; hBD 18, 400 bp product and human GAPDH, which was used as an internal control, 473-bp product. All products were amplified according to the conditions described in Table I. Cells were cultivated in a control well in the absence of $A$. fumigatus. As a positive control for defensin expression, exposure to human II- I $\beta$ was used in all experiments. The hBDI, hBD2 and hBD9 products were sequenced and confirmed to be identical to the predicted sequence. GAPDH was uniformly expressed. One of the four experiments is shown. Abbreviations: resting conidia (RC), swollen conidia (SC), hyphal fragments (HF), glyceraldehyde-3-phosphate dehydrogenase (GAPDH), interleukin-I $\beta$ (II-I $\beta$ ). and hBD9, in contrast to the exposure of the cells to the 5 $\times 10^{6}$ latex beads. The expression of hBD 8 and hBD18 by cells exposed to A. fumigatus was not observed in the present study. The constitutive expression of human beta defensin1 (hBD1) was found in the current experiment. Since polymixin B drastically inhibits endotoxin activity, $20 \mu \mathrm{g}$ of polymixin B per ml were added to cells before exposure to A. fumigatus organisms in some experiments, according to the method described by Mambula et al., in order to rule out endotoxin contamination [27]. This had no effect on defensin expression. Similar results were observed for A549 cells (data not shown). Therefore, hBD2 and hBD9 were chosen for further analysis of defensin expression by $16 \mathrm{HBE}$ and A549 cells exposed to A. fumigatus.

\section{Role of serum in defensin expression by human pneumocytes and tracheal epithelial cells exposed to $A$. fumigatus}

In order to investigate the potential role of the serum and to set up the experimental conditions necessary for analysing the inducible expression of defensins by the human respiratory epithelium exposed to A. fumigatus, $16 \mathrm{HBE}$ and A549 human airway epithelial cells were incubated with A. fumigatus organisms ( $\mathrm{HF}$ and SC or RC) or latex beads in the presence of either 10\% heterologous Fetal Calf Serum (FCS) or 5\% autologous human serum. Expression of hBD2 and hBD9 was evaluated. As a positive control, Il-1 $\beta$ was used in experiments. The cells were exposed to $10^{6}$ of $A$. fumigatus conidia or $20 \mu \mathrm{l}$ of $A$. fumigatus HF solution or $5 \times 10^{6}$ latex beads for various periods from $4 \mathrm{~h}$ to $18 \mathrm{~h}$. The representative results of defensin expression by the 16HBE cells exposed for 18 hours to $A$. fumigatus are shown in Figure 2. Higher hBD2 and hBD9 gene expression was observed in the untreated control cells and the cells exposed to the latex beads in the presence of heterologous FCS (Figure 2A), compared to the intensity of bands corresponding to hBD2 and hBD9 in the cells incubated in the presence of $5 \%$ autologous human serum (Figure 2B). The treatment of the cells with Il-1 $\beta$, as well as exposure of cells to either HF or conidia of A. fumigatus, strongly induced the expression of both defensins by the cells incubated with human serum (Figure 2B). Similar results were observed with A549 cells. The exposure of both types of cells to $10^{5}$ conidia resulted in defensin expression as well (data not shown).

Taking the lower basal level of defensin expression into account in untreated control cells maintained in the medium containing human serum compared to FCS, all of the following experiments, unless otherwise specified, were performed with human respiratory cells incubated in the presence of $5 \%$ human serum.

The identities of hBD2 and hBD9 defensins were confirmed by direct sequencing of the products of predicted 
Table I: Primer sequences, annealing temperatures and product size (RT-PCR).

\begin{tabular}{|c|c|c|c|}
\hline Primers & Sequences & Conditions & Product size \\
\hline $\begin{array}{l}\text { hBDIf } \\
\text { hBDIr }\end{array}$ & $\begin{array}{l}\text { 5'-agcgtctccccagttcctgaaatcct-3' } \\
5^{\prime} \text {-tcttctggtcactcccagctcacttg-3' }\end{array}$ & 38 cycles, $61^{\circ} \mathrm{C}$ & $273 \mathrm{bp}$ \\
\hline $\begin{array}{l}\text { hBD2f } \\
\text { hBD2r }\end{array}$ & $\begin{array}{l}5^{\prime} \text {-catcagccatgagggtcttg-3' } \\
3^{\prime} \text {-ggctttttgcagcattttgt- } 3^{\prime}\end{array}$ & $\begin{array}{l}38 \text { cycles, } 61^{\circ} \mathrm{C} \\
2.5 \% \text { DMSO }\end{array}$ & 199 bp \\
\hline $\begin{array}{l}\text { hBD8f } \\
\text { hBD8r }\end{array}$ & $\begin{array}{l}5^{\prime} \text {-tactcacctccagccttttgtcatcc-3' } \\
5^{\prime} \text {-gggtgtagtgctctcaattcttggttg-3' }\end{array}$ & 38 cycles, $61^{\circ} \mathrm{C}$ & 176 bp \\
\hline $\begin{array}{l}\text { hBD9f } \\
\text { hBD9r }\end{array}$ & $\begin{array}{l}5 \text { '-tgcagtaagaggtgatttgg-3' } \\
5 \text { '-tgacatgataagtggtgttgg- } 3^{\prime}\end{array}$ & 32 cycles, $56^{\circ} \mathrm{C}$ & $174 \mathrm{bp}$ \\
\hline $\begin{array}{l}\text { hBDI8f } \\
\text { hBDI8r }\end{array}$ & $\begin{array}{l}5^{\prime} \text {-cctgcttcccaaggaccatgaaactc-3' } \\
5^{\prime} \text {-ccgagaggaagtcatgagctatggtg- } 3 \text { ' }\end{array}$ & 38 cycles, $61^{\circ} \mathrm{C}$ & $400 \mathrm{bp}$ \\
\hline $\begin{array}{l}\text { GAPDHf } \\
\text { GAPDHr }\end{array}$ & $\begin{array}{l}5^{\prime} \text {-cccatcaccatcttccagagc- } 3^{\prime} \\
5^{\prime} \text {-ccagtgagcttcccgttcagc- } 3^{\prime}\end{array}$ & 32 cycles, $61^{\circ} \mathrm{C}$ & 473 bp \\
\hline
\end{tabular}

molecular weight generated by PCR amplification using upstream PCR primers.

\section{Effect of heat inactivation of serum on inducible defensin expression}

The mechanisms of regulation of beta defensin expression by airway epithelial cells exposed to A. fumigatus organisms are unknown; the autocrine mechanism of defensin induction by cytokines cannot be ruled out. It was reported that Aspergillus induced cytokine production

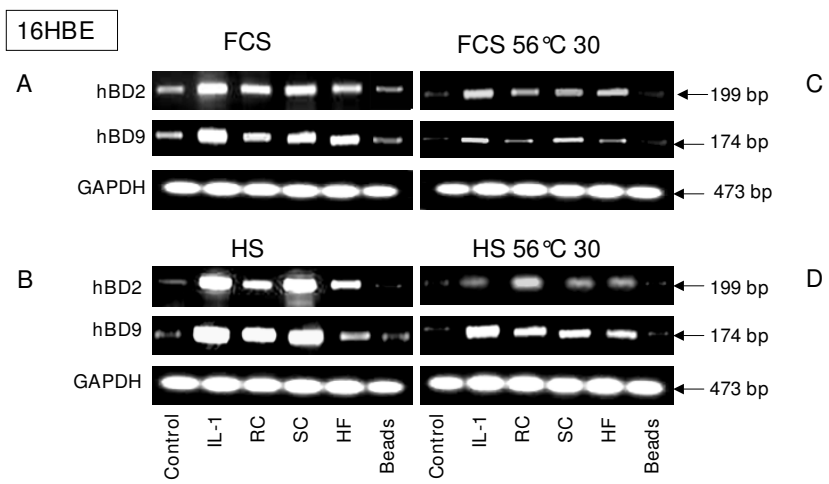

Figure 2

RT-PCR analysis of defensin expression by I6HBE cells exposed to $A$. fumigatus organisms in the presence of different serums. I6HBE human epithelial bronchial cells $\left(5 \times 10^{6}\right)$ were grown in six well plates for 24 hours. The cells were then exposed to the different morphotypes of $A$. fumigatus or the latex beads in the presence of either Human (HS) or Fetal Calf Serum (FCS), (heated or not at $56^{\circ} \mathrm{C}$ ). After 18 hours of incubation, the cells were washed with PBS, mRNA was isolated by TRIzol Reagent, and RTPCR was performed as described above in Materials and Methods. Specific primer pairs (Table I) were used for RNA amplification. The sizes of amplified products are indicated and were as predicted. All products were amplified according to the conditions described in Table I. Cells were cultivated in a control well in the absence of A. fumigatus. GAPDH was uniformly expressed. One of the four results is shown. whereas heat inactivation of serum decreased cytokine production $[28,29]$. We therefore checked to see of the heat-labile serum factor was required for defensin expression. To do this, human 16HBE cells were incubated either with heterologous FCS or autologous human serum (previously heated or not at $56^{\circ} \mathrm{C}$ for $30 \mathrm{~min}$ ) and simultaneously exposed for 18 hours either to A. fumigatus conidia, HF or the latex beads.

As shown in Figure 2, a high level of hBD2, as well as hBD9 expression, was observed in the cells incubated either with FCS (Figure 2A) or human serum (Figure 2B). Heat inactivation of any of the serums led to the partial decrease of the expression of both of the tested defensins by cells exposed either to $A$. fumigatus conidia, HF, or to Il$1 \beta$ (Figure 2C, D).

\section{Kinetics of defensin expression by cells exposed to A. fumigatus organisms}

To analyse the kinetics of defensin expression, cells were exposed to A. fumigatus for 4,8 and 18 hours, and the expression of hBD2 and hBD9 was examined. As a positive control, Il-1 $\beta$-treated cells were examined. As a negative control, untreated cells or cells exposed to $5 \times 10^{6}$ latex beads were analysed as well. According to the results presented on Figure 3, the expression of both defensins, hBD2 and hBD9, were induced in the 16HBE cells treated with Il-1 $\beta$ either for 4,8 or 18 hours. No hBD2 expression was detected after a 4 -h exposure by $16 \mathrm{HBE}$ to SC, RC or HF of A. fumigatus, in contrast to hBD9 expression by cells exposed to all morphotypes of A. fumigatus for the same period. Incubation of the cells with both types of conidia or HF for $8 \mathrm{~h}$ resulted in a low level of hBD2 expression and a high level of hBD9 expression, comparable to expression by the cells treated with the positive control, Il$1 \beta$. Exposure of the cells to conidia or HF for $18 \mathrm{~h}$ led to the high expression of both defensins, hBD2 and hBD9. Exposure of the cells to the latex beads did not induce the defensin expression in any of the experiments. The constitutive expression of hBD1 by the cells exposed either to 


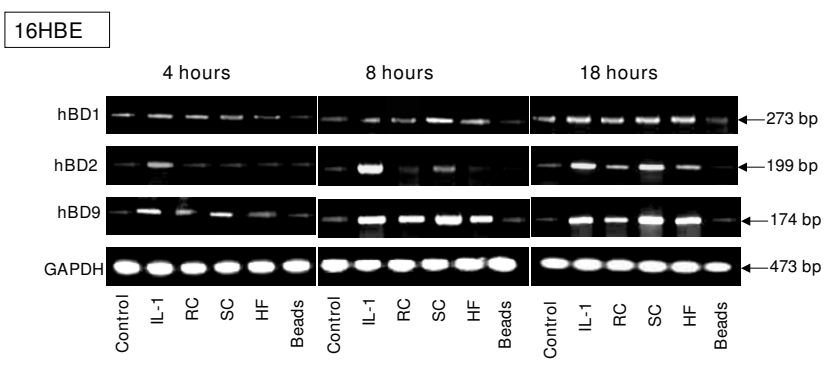

Figure 3

Kinetics of defensin mRNA expression by I 6 HBE human epithelial bronchial cells exposed to $A$. fumigatus organisms. I6HBE human epithelial tracheal cells $(5 \times$ $\left.10^{6}\right)$ were grown in six well plates for 24 hours. The cells were then exposed to the different morphotypes of $A$. fumigatus or latex beads for the different periods: $4 \mathrm{~h}, 8 \mathrm{~h}$ and 18 h. After incubation, the cells were washed with PBS, mRNA was isolated by TRIzol Reagent, and RT-PCR was performed as described above in Materials and Methods. Specific primer pairs and the conditions of RT-PCR are described in Table I. The sizes of amplified products are indicated and were as predicted: hBD2, 199-bp product; hBD9, 174 bp product and human GAPDH, 473-bp product. The hBD2 and hBD9 products were sequenced and confirmed to be identical to the predicted sequence. Cells were cultivated in a control well in the absence of $A$. fumigatus. GAPDH was uniformly expressed. One of the four results is shown.

the different morphotypes of $A$. fumigatus or to the latex beads for the various periods was observed in the current experiment.

Similar kinetics of hBD2 and hBD9 expression was observed with A549 cells (data not shown).

\section{Real time PCR}

The relative level of hBD2 and hBD 9 expression in 16HBE and A549 cells exposed to different A. fumigatus morphotypes for 18 hours was quantified by real time PCR. The expression of both defensins was higher in Il-1 $\beta$ stimulated cells than in the control, as shown for $16 \mathrm{HBE}$ cells in Figure 4. Exposure of $16 \mathrm{HBE}$ cells to SC resulted in a statistically significant increase of hBD2 and hBD9 expression compared to that of the untreated control cells or the cells exposed to the latex beads. The increase of defensin expression was also found in the cells exposed to RC and HF. However, this difference was significant only for hBD9 in the cells exposed to RC. The difference in expression of hBD2 by the cells exposed to RC and in the expression of hBD2 as well as hBD9 by the cells exposed to HF did not reach a significant level. There was no difference between defensin expression in the untreated control cells and the cells exposed to the latex beads. Similar results were obtained with A549 cells.

\section{Neutralising anti-interleukine-I antibody decreased} defensin expression in cells exposed to swollen conidia Since A. fumigatus has been shown to induce IL- $1 \beta$ in airway epithelium, and since the analysis of kinetic of defensin expression showed that the Il-1 $\beta$-induced response was faster than the one induced by fungi (Figure 3 ), we investigated whether or not observed A. fumigatusinduced defensin expression was related to Il-1 $\beta$ synthesized during anti-fungal response. For this reason, neutralising anti-interleukine- $1 \beta$ antibody was added to the cells before exposure to A. fumigatus organisms. One of the defensins, hBD-9, was chosen for real time PCR analysis of the role of Il-1 $\beta$ in defensin expression. The results of real time PCR revealed that relative gene expression was statistically significantly decreased in the cells treated with anti-Il-1 $\beta$ antibody before exposure to SC, compared to the cells only exposed to SC $(120 \pm 5$ versus $143 \pm 10$ respectively). Relative gene expression was also decreased in the cells treated with anti-Il-1 $\beta$ antibody before exposure to $\mathrm{RC}$ or $\mathrm{HF}$, but the difference did not reach a statistically significant level. The pre-treatment of the cells with normal mouse immunoglobulin before exposure to $A$. fumigatus organisms had no effect on defensin expression.

\section{Analysis of defensin expression by human primary airway epithelial cells exposed to A. fumigatus conidia or hyphal fragments}

To provide evidence for the biological significance of the discovered phenomenon, we verified whether or not inducible defensin expression was observed in the human primary airway epithelial cells, in addition to the detected defensin expression in airway cell lines A549 and 16HBE (described above). Airway epithelial cells obtained from human nasal turbinates (HNT) of patients undergoing turbinectomy were exposed to RC, SC or HF or latex beads for 18 hours. Examination of hBD2 or hBD9 expression showed that both defensins were detected by RT-PCR in the primary culture cells exposed to all of the morphotypes of A. fumigatus (Figure 5). The relative level of hBD2 and hBD9 expression in HNT cells was quantified by real time PCR. The expression of both defensins was higher in Il-1 $\beta$ stimulated cells than in the control, as shown in Figure 6. Exposure of HNT cells to SC resulted in a statistically significant increase of hBD2 and hBD9 expression compared to that of the untreated control cells or the cells exposed to the latex beads. The increase of defensin expression was also found in the cells exposed to RC and HF. However, this difference was significant only for hBD2 in the cells exposed to RC. The difference in expression of hBD 9 by the cells exposed to RC and in the expression of hBD2 as well as hBD9 by the cells exposed to HF did not reach a significant level. There was no difference between defensin expression in the untreated control cells and the cells exposed to the latex beads. 


\section{$16 \mathrm{HBE}$}
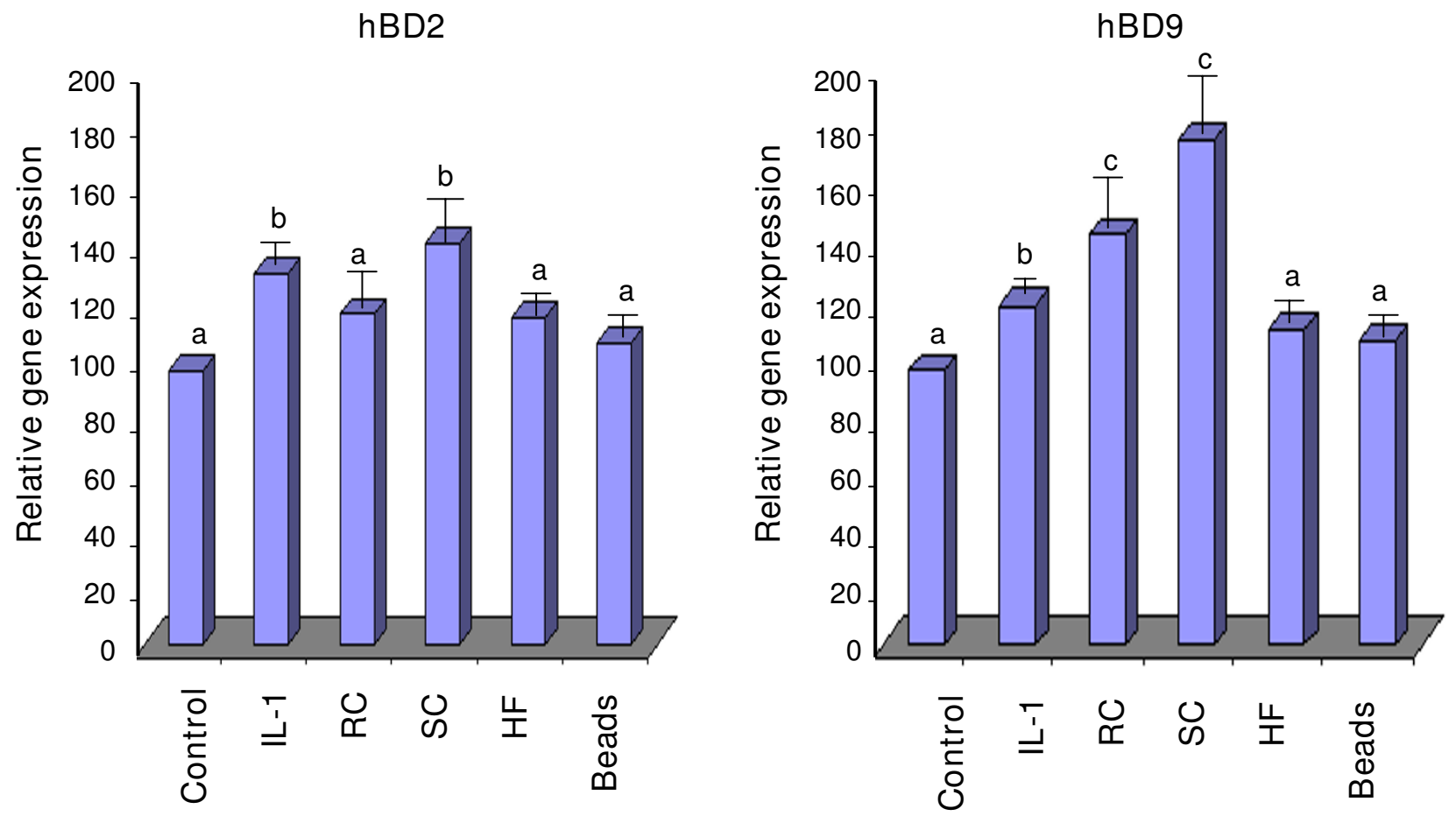

Figure 4

Analysis of mRNA levels for HBD2 and HBD9 in $16 \mathrm{HBE}$ cells exposed to A. fumigatus organisms. $16 \mathrm{HBE}$ cells $(5$ $\times 10^{6}$ ) were grown in six well plates for 24 hours. The cells were then exposed to the different morphotypes of $A$. fumigatus or latex beads for $18 \mathrm{~h}$. Cells were cultivated in a control well in the absence of $A$. fumigatus or the latex beads. Isolation of total RNA and synthesis of cDNA was performed as described in Methods. Specific primer pairs and the conditions of real time PCR are described in Table 2. The level of mRNA for defensins was measured in total RNA preparation by quantitative real time $\mathrm{PCR}$ as described in Methods. Expression of all genes was normalised to the expression of the endogenous reference gene GAPDH. The expression value in control cells was used as the baseline. Data are calculated from three different experiments performed in triplicate. Means followed by the same letter are not significantly different.

Detection of the hBD2 peptide in human airway epithelial cells by immunofluorescence

To determine if defensin peptides were present in the airway epithelial cells exposed to A. fumigatus, the hBD2 peptide was detected by immunofluorescence. Analysis of the hBD9 peptide was not performed since anti-hBD9 antibodies were not available. A549 or 16HBE cells were cultured on cover slips, subsequently exposed to either SC, $\mathrm{RC}, \mathrm{HF}$, latex beads or treated with Il-1 $\beta$ for $18 \mathrm{~h}$, and stained with polyclonal anti-hBD2 antibody as described in Methods. As shown in Figure 7A, hBD2 was detected in the cytoplasm of airway epithelial $16 \mathrm{HBE}$ cells exposed to any of the morphotypes of $A$. fumigatus, but generally not in the untreated control culture or in the cells exposed to the latex beads, except for several individual cells that contained some amount of defensin peptides. These findings are consistent with the inducible expression of hBD2. Staining revealed the punctuated distribution of peptides in the cytoplasm with a concentration in the perinuclear region. It should be observed that the expression of the hBD2 peptide was not detected in each cell of the sample exposed to A. fumigatus. Quantification of the differences in the number of cells detected with anti-defensin-2 antibody showed that the number of stained cells in the untreated control culture was $8 \pm 4 \%$. The percentage of stained cells increased to $32 \pm 4.6 \%$ after Il- $1 \beta$-treatment, to $17 \pm 4.5 \%$ after exposure to $\mathrm{RC}$, to $28 \pm 5.2 \%$ after exposure to SC and to $20 \pm 5.1 \%$ after exposure to HF, while exposure to the latex beads did not affect defensin expression $(9 \pm 3.9 \%)$ (Figure $7 B)$. Similar results were obtained with A549 cells (data not shown). 


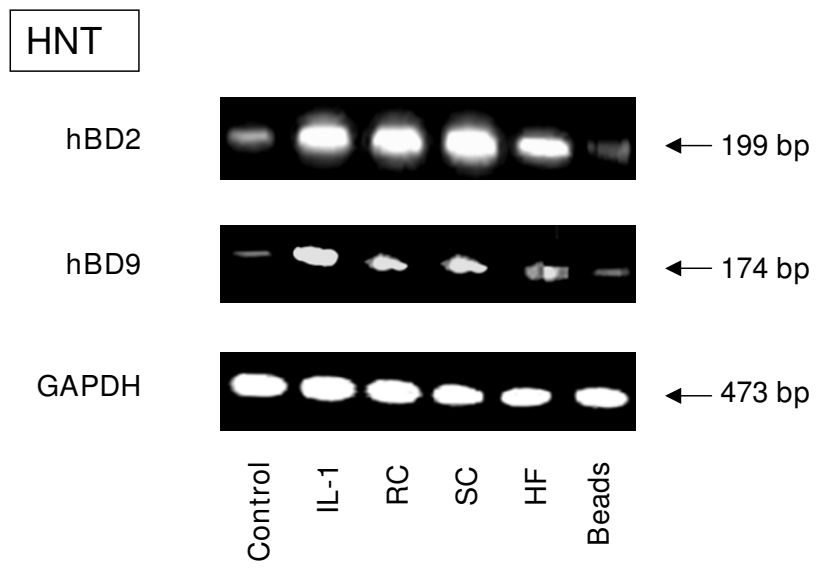

Figure 5

RT-PCR analysis of defensin mRNA expression by primary epithelial cells. Primary epithelial cells were obtained from human nasal turbinates (HNT), as described in Methods. The cells $\left(5 \times 10^{6}\right)$ were grown in the six well plates for 48 hours. The cells were then exposed to either the latex beads or $A$. fumigatus organisms for 18 hours. The mRNA was then isolated by TRIzol Reagent and RT-PCR was performed as described above in Materials and Methods. Specific primer pairs (Table I) were used for RNA amplification. The sizes of amplified products are indicated and were as predicted. The hBD2 and hBD9 products were sequenced and confirmed to be identical to the predicted sequence. GAPDH was uniformly expressed. Cells in a control well were cultivated in the absence of $A$. fumigatus. One of the three results is shown.

\section{Co-localisation of hBD-2 and different A. fumigatus morphotypes}

Previous experiments showed that human airway epithelial cells A549 internalised A. fumigatus conidia; a phagocytosis rate of $30 \%$ has been reported [30]. More then $50 \%$ of internalised conidia were found to co-localise after 24 hours with lysosomal proteins, CD63 and LAMP1 , which revealed the maturation of late endosome into lysosomes [31]. Similar results were obtained with primary human nasal epithelial cells. Staining of the cells with antibody against LAMP-1 demonstrated a positive immunofluorescence signal around digested $A$. fumigatus conidia [32]. Using the method described by these authors, we determined if different $A$. fumigatus morphotypes were co-localised with intracellular hBD-2. Labelling A549 cells with anti-hBD-2 antibody revealed cytoplasmic distribution of peptides. Comparison of the image of A549 cells stained by anti-hBD-2 antibody and the phase-contrast image revealed a positive immunofluorescence signal around resting (Figure $8 \mathrm{~A}, \mathrm{~B}$ ) or swollen (Figure $8 \mathrm{E}, \mathrm{F}$ ) conidia. This suggests a co-localisation of hBD2 and digested RC or SC. In contrast, no positive immunofluorescence signal was detected around HF, whereas the cells were positively stained with anti-human hBD2 antibody (Figure 8I, J). The normal rabbit serum control labels neither cytoplasm nor A. fumigatus morphotypes (Figure 8C, D, G, H, K, L). Similar results were obtained with 16 HBE cells.

\section{Quantification of hBD2 in cells supernatants by sandwich ELISA}

In order determine if synthesized $\mathrm{hBD} 2$ was released to cell supernatants, the level of hBD2 in the supernatants of $16 \mathrm{HBE}, \mathrm{A} 549$ and HNT primary culture cells was evaluated by sandwich-ELISA. As shown in Figure 9, 140, 150 and $100 \mathrm{pg} / \mathrm{ml}$ of hBD2 were detected in the supernatants of Il-1 $\beta$-treated $16 \mathrm{HBE}$, HNT and A549 cells, respectively. Comparable levels of hBD2 were detected in the supernatants of all cells exposed to SC: 100,180 and $70 \mathrm{pg} / \mathrm{ml}$ were found in the supernatants of 16HBE, HNT and A549 cells, respectively, which was statistically significantly higher then hBD2 levels in the supernatants of the cells alone or the cells exposed to RC, HF or latex beads. Exposure of any cells to RC or HF resulted in lower levels of hBD2, ranging from 20 to $70 \mathrm{pg} / \mathrm{ml}$. The difference between hBD2 levels in the supernatants of the cells exposed to either RC, or those exposed to latex beads, was statistically significant for HNT cells, while this difference did not reach statistically a significant level for A549 and $16 \mathrm{HBE}$ cells. This could be explained by the different reactions of the different kinds of cells to the pathogen. The difference between hBD2 levels in the supernatants of $16 \mathrm{HBE}, \mathrm{HNT}$ and A549 cells exposed to either RC, or those exposed to latex beads, was statistically insignificant.

\section{Analysis of hBD2 expression by airway epithelial cells exposed to live $A$. fumigatus}

In order to determine if hBD2 expression was induced in the respiratory cells by live A. fumigatus organisms, RTPCR and immunofluorescence analysis of cells exposed to unfixed $10^{6}$ live conidia was performed. Using microscopic observation, we first examined the development of A. fumigatus in the environment of the epithelial A549 or $16 \mathrm{HBE}$ cells. When the RC were added to the epithelial cells, they settled onto the cells within 30 minutes and began to swell after 3-4 hours; after 8 hours of infection, the SC became polarised and began to germinate. The germ tubes then progressively elongated, forming the hyphae: after 18 hours of infection, the hyphae had completely covered the epithelial cells (data not shown).

RT-PCR analysis of the A549 cells exposed to live A. fumigatus RC for 4, 8 and 18 hours allows us to detect hBD2 expression after 18 hours of incubation (Figure 10A), whereas no inducible hBD2 expression was observed after 4 or 8 hours of incubation (data not shown). Treatment of A549 cells either with IL-1 $\beta$ or TNF- $\alpha$ for 18 hours 


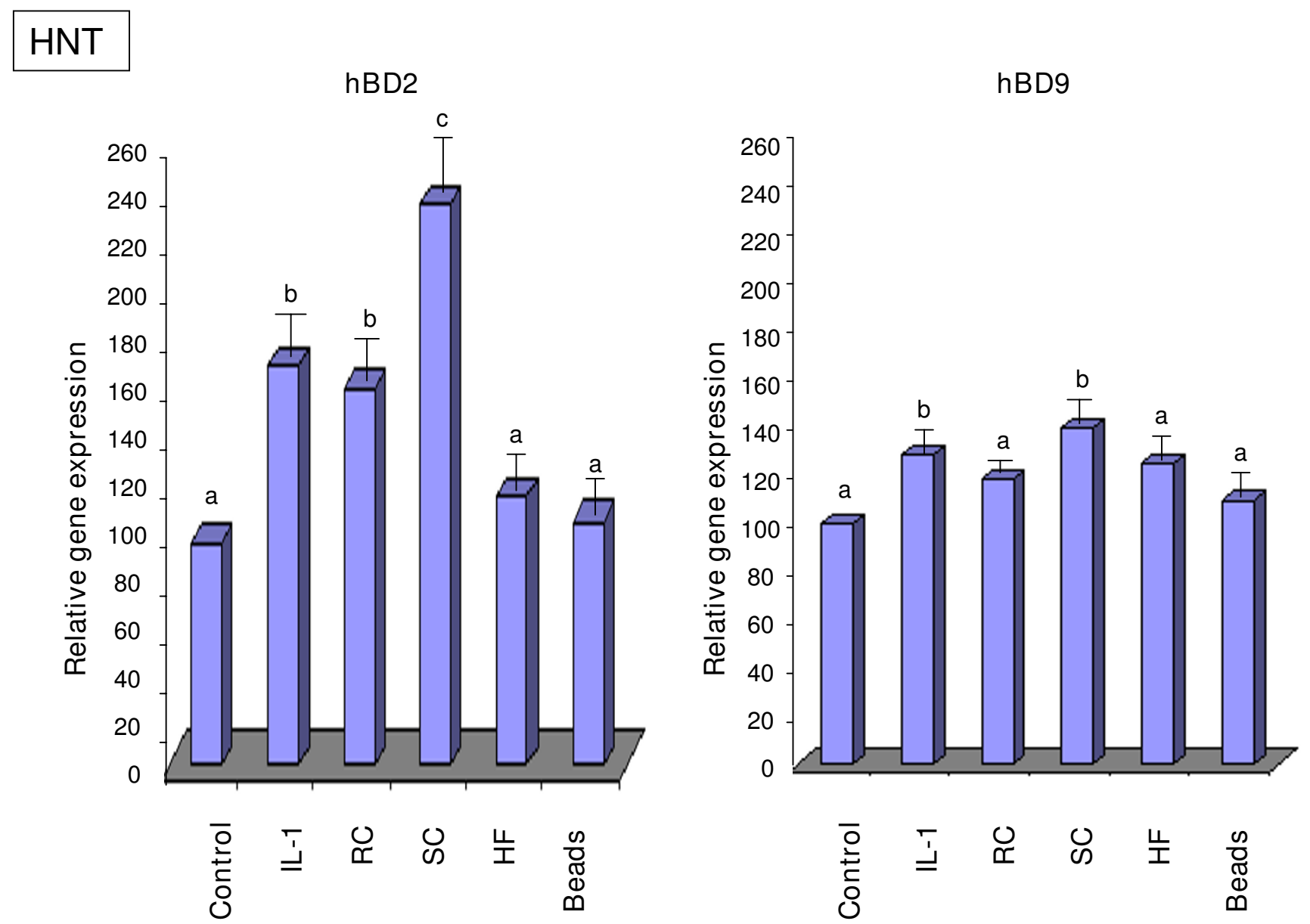

Figure 6

Analysis of mRNA levels for HBD2 and HBD9 in HNT primary culture cells exposed to A. fumigatus organisms. Primary epithelial HNT cells $\left(5 \times 10^{6}\right)$ were grown in six well plates for 48 hours. The cells were then exposed to the different morphotypes of $A$. fumigatus or latex beads for $18 \mathrm{~h}$. Cells were cultivated in a control well in the absence of $A$. fumigatus or the latex beads. Isolation of total RNA and synthesis of cDNA was performed as described in Methods. Specific primer pairs and the conditions of real time PCR are described in Table 2. The level of mRNA for defensins was measured in total RNA preparation by quantitative real time PCR as described in Methods. Expression of all genes was normalised to the expression of the endogenous reference gene GAPDH. The expression value in control cells was used as the baseline. Means followed by the same letter are not significantly different.

resulted in the inducible hBD2 expression. Detection of hBD2 in epithelial cells exposed to live A. fumigatus conidia for 18 hours by the immunofluorescence method revealed punctuated distribution of peptides in the cytoplasm with a concentration in the perinuclear region, similar to the staining of hBD2 in cells exposed to ethanolfixed conidia or HF (Figure 10C). Several individual cells were stained with anti-hBD2 antibody in the untreated control cells or in cells exposed to the latex beads. Quantification of cells stained with hBD antibody revealed the increase in the number of stained cells from $6 \pm 4.8 \%$ in the untreated control cells to $32 \pm 5.7 \%$ in the IL- $1 \beta$ treated culture, to $19 \pm 6 \%$ in TNF-treated culture and to
$35 \pm 4.7 \%$ in the cells exposed to live A. fumigatus, compared to $8 \pm 4 \%$ cells in the culture exposed to $5 \times 10^{6}$ latex beads (Figure 10B).

\section{Transcriptional and post-transcriptional mechanisms of defensin expression regulation}

In order to determine if the observed increase of defensin (hBD2 and hBD9) expression by cells exposed to A. fumigatus was related to transcriptional activation or enhanced stabilisation of mRNA, 16HBE cells were pre-treated with $0.5 \mu \mathrm{g}$ of actinomycin D (an inhibitor of RNA transcription) per $\mathrm{ml}$, or DMSO (vehicle control), $1 \mathrm{~h}$ before exposure of the cell to conidia or HF for an additional 8 or18 


\section{HBE}

A

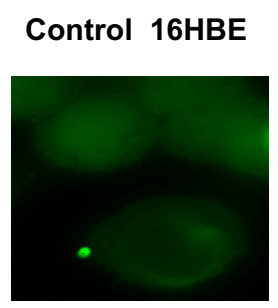

16HBE+SC

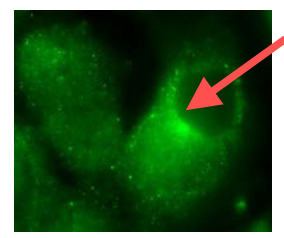

$16 \mathrm{HBE}+\mathrm{IL}-1 \beta$

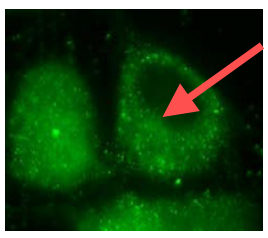

16HBE+HF

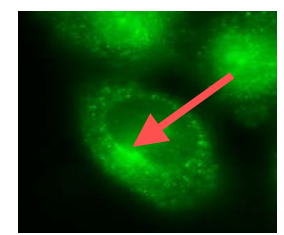

16HBE+RC

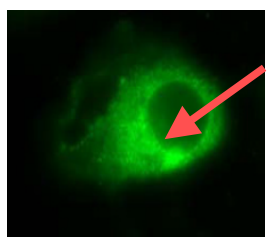

16HBE+Beads

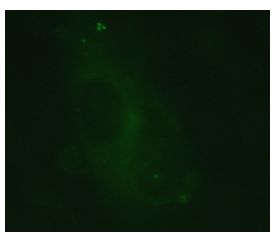

B

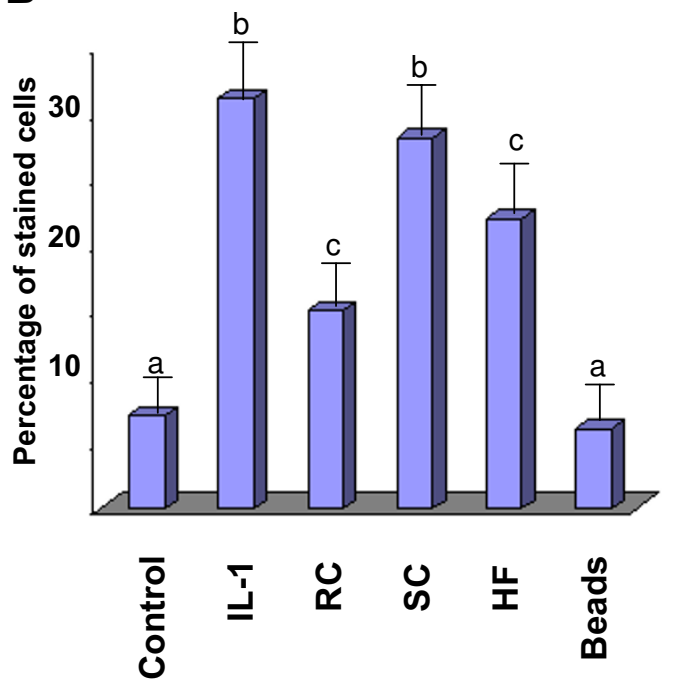

Figure 7

Localisation of the hBD2 peptide in epithelial bronchial $16 \mathrm{HBE}$ cells. I6HBE cells were seeded at $5 \times 10^{5}$ cells per well in I ml of DMEM/FI 2 on I8-mm-diameter cover slips in 12 well plates in triplicate and grown for $16 \mathrm{~h}$ at $37^{\circ} \mathrm{C}$. After washing the cover slips with PBS-BSA, the cells were exposed to either latex beads, ethanol fixed conidia or ethanol fixed HF for 18 hours. II-I $\beta$ was used as a positive control. Following washing with PBS, the cells were fixed with a paraformaldehyde solution for $30 \mathrm{~min}$ at $37^{\circ} \mathrm{C}$. The slides were then incubated in $1 \%$ BSA/PBS-Triton $0.05 \%$, followed by a solution of $10 \%$ normal goat serum. After washing, polyclonal rabbit anti-human hBD2 at a dilution of I:250 was applied as primary antibody overnight at $4^{\circ} \mathrm{C}$, followed by incubation with FITC-labelled goat anti-rabbit secondary antibody at a dilution of I:300 for 4 hours at room temperature. After washing, the cover slips were mounted on slides with ProLong antifade Vectashield. Samples were viewed with a Zeiss fluorescence microscope using $\times 400$ magnification. The arrows indicate the cells stained with anti-hBD2 antibody. The percentage of stained cells was computed from triplicates of four experiments. Means followed by the same letter are not significantly different. +, presence; -, absence of II-I $\beta, A$. fumigatus fixed organisms and latex beads. The punctuated localisation of the signal, which is concentrated adjacent to the nucleus (arrow), was observed. The data shown are representative of four independent experiments.

$\mathrm{h}$, as described in the literature [33]. The viability of $16 \mathrm{HBE}$ cells and total RNA yield were verified after each treatment, and there was no difference between treated and untreated control cells. As shown in Figure 11, exposure of the $16 \mathrm{HBE}$ cells either to DMSO or Act D resulted in almost no increase of defensin expression compared to control cells, while the expression of both defensins by the $16 \mathrm{HBE}$ cells exposed to the various forms of A. fumigatus conidia for either 8 or $18 \mathrm{~h}$ was inhibited by the pretreatment of cells with Act D. Therefore, the data indicated that new gene transcription is required for hBD2 and hBD9 expression by cells exposed to A. fumigatus RC, SC or HF.

To determine if the increase in defensin mRNA expression was dependent on protein synthesis, 16HBE cells were pre-treated with $2.5 \mu \mathrm{g}$ of cycloheximide (CHX), a protein synthesis inhibitor, $1 \mathrm{~h}$ before exposure to A. fumigatus. Pre-treatment of the cells with only $\mathrm{CXH}$ did not change defensin expression, compared to control cells. In contrast, pre-treatment of $16 \mathrm{HBE}$ cells with $\mathrm{CXH}$ resulted in the inhibition of defensin expression after exposure to $A$. fumigatus (Figure 12). Therefore, it could be hypothesized that protein synthesis might be required for induced accumulation of defensin mRNA.

\section{Discussion}

A better understanding of the mechanisms responsible for the defence against invasive Aspergillus infection is required to develop strategies aimed at boosting the antifungal actions of the immune system. Defensins, or antimicrobial peptides, which are implicated in potentiating 

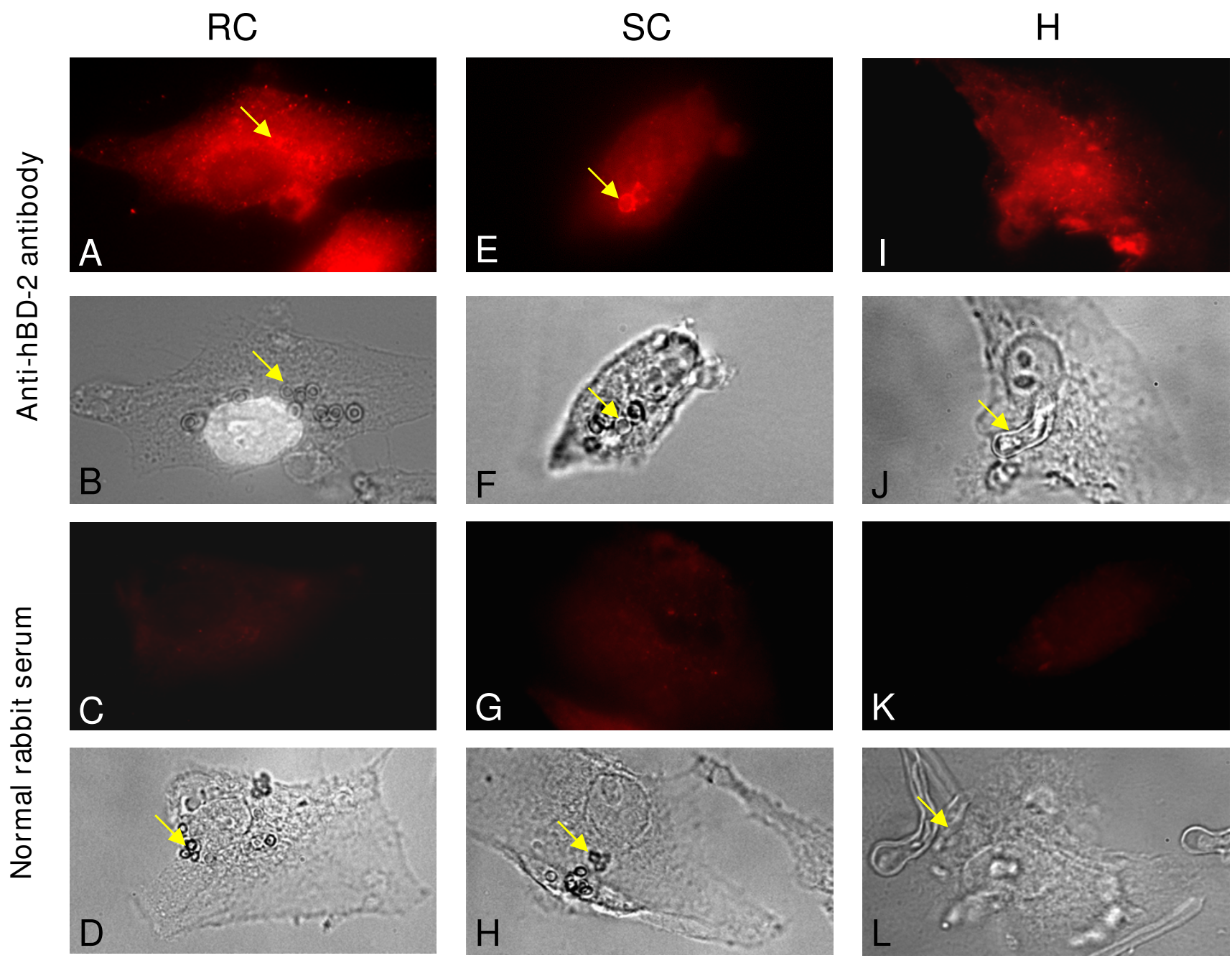

Figure 8

Co-localisation of hBD2 and A. fumigatus organisms. A549 cells were grown on cover slips for $16 \mathrm{~h}$ at $37^{\circ} \mathrm{C}$. Cells were exposed to RC (A, B, C, D), SC (E, F, G, H) or HF (I, J, K, L) for 18 hours at $37^{\circ} \mathrm{C}$. After fixation and permeabilisation, as described for Figure 7, cells were labelled with specific anti-hBD-2 antibody (A, B, E, F, I, J) and secondary antibody conjugated to Texas-red. Normal rabbit serum was used instead of anti-hBD2 as a negative control (C, D, G, H, K, L). Immunofluorescence signal (A, E, I, C, G, K) was compared to phase contrast image of the same cells $(B, F, G, D, H, L)$. Arrows indicated different $A$. fumigatus morphotypes.

innate and adaptive immunity [16-18] in addition to direct antimicrobial activities [20], would be a good candidate as a therapeutic agent for enhancing host defence mechanisms. Since the invasion of the airway epithelium by A. fumigatus conidia may play an important role in the development of aspergillosis, we therefore investigated the involvement of defensins in the response of pneumocytes A549 and bronchial epithelial cells 16HBE exposed to A. fumigatus in this study. The expression of human defensins hBD1, hBD2, hBD8, hBD9 and hBD18 was analysed. In agreement with earlier findings [34], constitutive expression of hBD1 by the epithelial cells $16 \mathrm{HBE}$ and A549 was observed in our experiments. It was found that
hBD2 and hBD9 are highly expressed by the epithelial respiratory cells exposed to SC, RC or HF of A. fumigatus, while hBD 8 and hBD18 gene expression was not observed in the current study. Previous investigations revealed that hBD2 was induced by various stimuli including microbes, cytokines and growth factors [33,35]. Inducible expression of hBD2 defensins by airway epithelial cells exposed to A. fumigatus, observed in the present work, is therefore in agreement with earlier observations. The role of the recently discovered hBD 9 in innate antimicrobial defence is not well determined; however, hBD9 gene regulation in gingival keratinocytes exposed to Candida albicans has been described [36]. Additional investigations are essen- 


\section{$16 \mathrm{HBE}$}

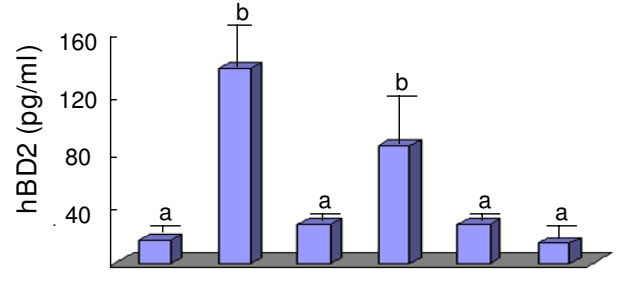

HNT

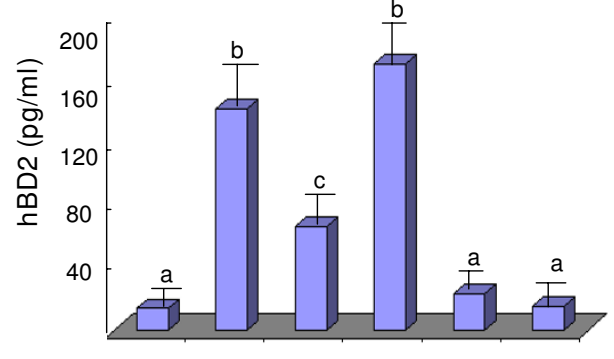

A549

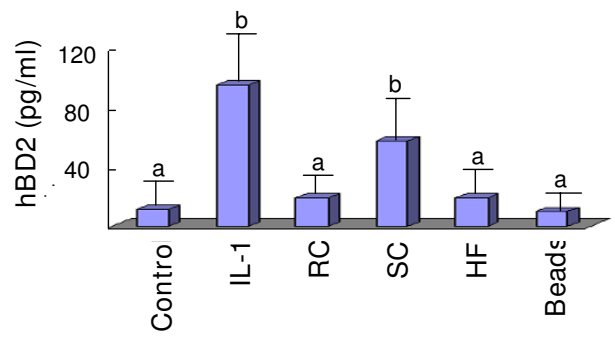

\section{Figure 9}

Analysis of hBD2 level in cell supernatants. The level of hBD2 in supernatants of $16 \mathrm{HBE}, \mathrm{A} 549$ and primary culture HNT cells was measured by sandwich-ELISA. Briefly, cells were grown and exposed to different $A$. fumigatus organisms, latex beads or II-I $\beta$ (positive control) for 18 hours at $37^{\circ} \mathrm{C}$. Supernatants were collected as described in Methods. The level of hBD was computed from duplicates of three experiments. Means followed by the same letter are not significantly different.

tial for a better understanding of its role in direct antimicrobial activity and its contribution to innate immunity. The role of hBD 8 and hBD18 in innate immunity of respiratory epithelium exposed to A. fumigatus cannot be ruled out before evaluation of other epithelial respiratory cells or other induction conditions. Further analysis of those defensins is recommended.

We have shown that the maintenance of the human epithelial cells in the presence of preheated serum $\left(56^{\circ} \mathrm{C}\right.$ for $30 \mathrm{~min}$ ) resulted in the partial decrease of defensin expression. Involvement of the heat-labile serum factor suggests the potential role of the complement for defensin expression. The possible link between the proteins of the complement system and defensin expression may be anticipated since the interaction between the defensins and proteins of the complement system was demon- strated. It was found that HBD2 inhibits the classical pathway of the complement system [37]. Moreover, the interrelationship between the respiratory tract and the complement system was studied in an animal model [38]. The origin of complement proteins present in the lining fluid of the respiratory tract is thought to result mainly from plasma that exudes into the bronchoalveolar space. However, it was shown that human bronchial epithelial cells generate complement protein $\mathrm{C} 3$ : the modulation of its expression by proinflammatory cytokines might be an additional regulatory mechanism of local airway defence during infection [39].

Furthermore, the kinetics of the expression of human beta defensins, hBD2 and hBD9, by airway epithelial cells exposed to the deferent morphotypes of A. fumigatus was analysed. Analysis of the kinetics of hBD2 and hBD9 defensin expression by cells exposed to A. fumigatus showed the prompt inducible expression of hBD9, following by delayed hBD2 expression. This could allow us to hypothesize that the host immune system may react against $A$. fumigatus by using the cascade of newly synthesized defensins that probably possess the different functions. However, this hypothesis would require further investigation at the protein level. Our data are in agreement with the analysis of kinetics of hBD2 expression by A549 cells exposed to Mycobacterium tuberculosis; infection of A549 cells resulted in hBD2 gene expression as early as 6 hours postinfection, while maximum expression was detected at 18 and 24 hours postinfection [35].

Several lines of evidence eliminated the possibility that observed inducible defensin expression was related to endotoxin contamination of A. fumigatus organisms. First, the addition of Polymixin $B$ (known for its endotoxinneutralising activity) to the cells prior to exposure to $A$. fumigatus organisms did not have any effect on defensin expression. Second, rigorous measures were undertaken to keep endotoxin out of the experimental system, including washing of $A$. fumigatus organisms with the solution containing Polymixin B during preparation, utilisation of endotoxin-free plasticware and solutions in experiments, and washing of fungal organisms in endotoxin-free PBS prior to use.

The expression of hBD2 and hBD9 was found to be higher in A549, 16HBE and primary culture HNT cells exposed to SC compared to RC or HF, as shown by quantitative PCR. During asexual growth, the morphological form of $A$. fumigatus changes from resting to swollen conidia, which then form germ tubes that continue growing in hyphal form. These transformations are accompanied by the modification of surface structures. The $\mathrm{RC}$ are covered with a proteinoceous layer that is disrupted during swelling, exposing the inner layer. Therefore, the surfaces of 


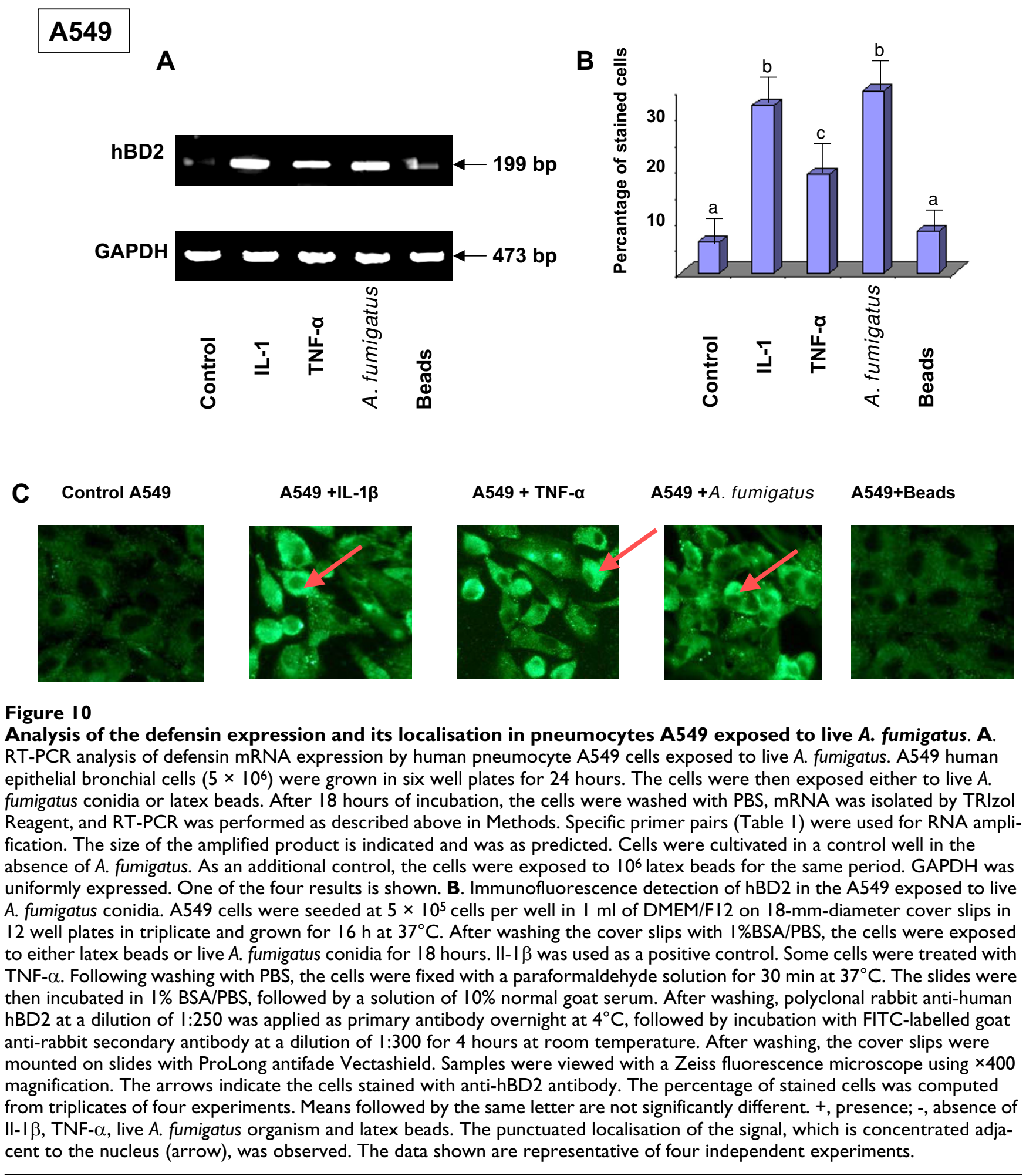




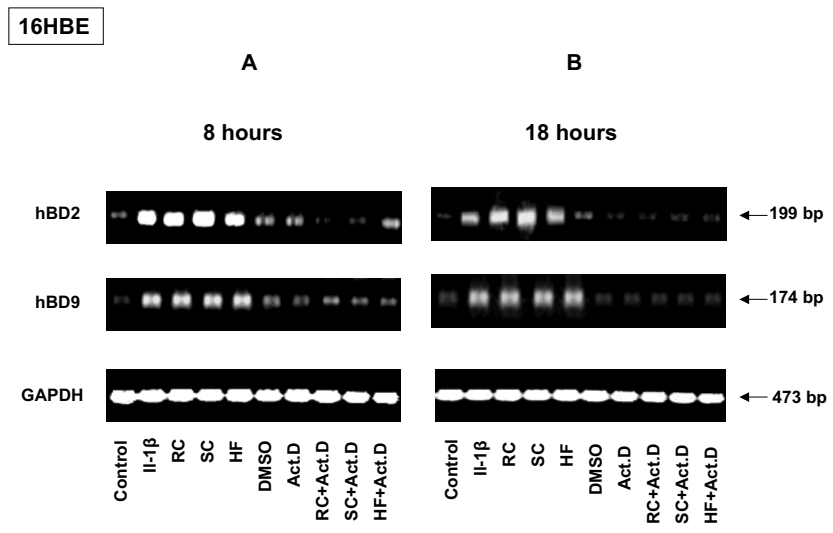

Figure I I

Effect of RNA synthesis inhibition on inducible defensin expression. I6HBE human epithelial bronchial cells $\left(5 \times 10^{6}\right)$ were grown in six well plates for 24 hours. The cells were then pre-treated with I mg of actinomycin D/ $\mathrm{ml}(\mathrm{ActD})$ or DMSO solvent for I h, and some samples were then exposed to the different morphotypes of $A$. fumigatus either for 6 (Figure 7A) or for 18 (Figure 7B) hours. There was no significant difference in viability between control and treated cells as assessed by staining with trypan blue. Furthermore, the yields of total RNA from the samples were compared and showed no difference. Total RNA was extracted and analysed by RT-PCR. The sizes of amplified products are indicated and were as predicted. GAPDH was uniformly expressed. Complete inhibition of hBD2 and hBD9 expression by the cells exposed to $A$. fumigatus, either for 6 or for 18 hours was observed after pre-treatment of the cells with actinomycin $\mathrm{D}$.

various A. fumigatus morphotypes differ form each other and, consequently, the reaction of host cells may vary towards divergent A. fumigatus growth forms [40]. Our findings suggest that infected hosts can discriminate between inactive RC and active potentially-invasive SC. The data are consistent with findings showing that SC (the mature form of A. fumigatus), but not RC-activated NF-k $\beta$, stimulated pro-inflammatory cytokines and the production of reactive oxygen by host macrophages [40].

Moreover, the presence of the hBD2 peptide in the respiratory cells was investigated. Detection of the hBD2 peptide by immunofluorescence in A549 and 16HBE cells exposed to the different forms of A. fumigatus confirmed its inducible expression in the infected cells. The presence of the negatively-stained cells in the infected culture may be due to defensin synthesis in the subpopulation of the epithelial cells or because of the release of synthesized defensins by the activated cells. The detection of the betadefensin hBD2 peptide in the individual unstimulated control cells is in agreement with the observation made for the alpha-defensins; it has been reported that individ-

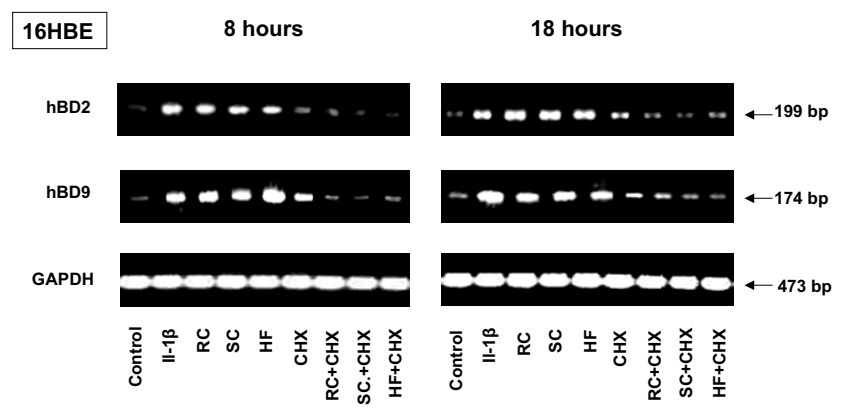

Figure 12

Effect of protein synthesis inhibition on inducible defensin expression. 16HBE human epithelial tracheal cells $\left(5 \times 10^{6}\right)$ were grown in six well plates for 24 hours. The cells were then pre-treated with $2.5 \mu \mathrm{g}$ of cycloheximide ( $\mathrm{CHX}$ ) for I $\mathrm{h}$, and some samples were then exposed to the different morphotypes of $A$. fumigatus, either for 6 (Figure $8 \mathrm{~A}$ ) or for 18 (Figure $8 \mathrm{~B}$ ) hours. There was no significant difference in viability between control and treated cells as assessed by staining with trypan blue. Furthermore, the yields of total RNA from the samples were compared and showed no difference. Total RNA was extracted and analysed by RTPCR. The sizes of amplified products are indicated and were as predicted. GAPDH was uniformly expressed. Complete inhibition of $h B D 2$ and $h B D 9$ expression by the cells exposed to $A$. fumigatus either for 6 or for 18 hours was observed after pre-treatment of the cells with cycloheximide.

ual untreated HL-60 cells may contain variable amounts of alpha defensin, as assessed by immunostaining [41]. Undoubtedly, inducible expression of defensin by cells exposed to A. fumigatus may represent the recruitment of additional cells that would synthesize antimicrobial peptides and further upregulation of defensin synthesis in cells that originally contained defensin. Punctuated distribution of peptide in the cytoplasm of A549 and 16HBE cells with a concentration in the perinuclear region was similar to the staining of defensin expressed by human gingival epithelial cells exposed to cell wall extract of the gram-negative periodontal bacteria, Fusobacterium nucleatum [33], suggesting that the mechanism of defensin expression may be universal for the different infectious agents. The punctuated perinuclear pattern of immunostaining may be related to the localisation of hBD2 in the endoplasmic reticulum and Golgi apparatus, which is in agreement with the previous observations of Rahman et al., showing that the hBD2 peptide was expressed in rough endoplasmic reticulum, the Golgi complex and cytoplasmic vesicles of human colon plasma cells [42]. Quantification of the cells stained with anti-hBD2 antibody revealed that SC induced a greater number of cells that synthesized hBD2, compared to RC and HF. Analysis 
of hBD2 levels in the supernatants of A549, $16 \mathrm{HBE}$ and primary culture HNT cells confirmed this observation; significantly higher hBD2 levels were detected in all tested cell supernatants exposed to SC, compared to those exposed to RC, HF or latex beads. The level of hBD2 detected in the cell supernatants does not exceed $200 \mathrm{pg} /$ $\mathrm{ml}$ and was comparable to the level of hBD2 in cell supernatants exposed to other pathogens [43]. Since Okamoto et al. showed that the effective dose of synthetic hBD2 was $1.5 \mu \mathrm{g} / \mathrm{ml}$, we can hypothesize that the chemotactic activity of hBD2 rather then its direct antifungal activity plays a more important role in the protection of the infected host [20]. However, antifungal activity of defensins in synergy with other antifungal factors in vivo cannot be excluded.

Co-localisation analysis of hBD2 and A. fumigatus morphotypes allow us to detect RC or SC stained with hBD2 antibody in contrast to HF; these observations confirm the different mechanism of hBD2 induction by various morphotypes. Our findings are in agreement with the observations of Lopez Bezzera et al. who found that A. fumigatus conidia and hyphae injure endothelial cells via different mechanisms [44]. This difference between the different growth phases of $A$. fumigatus could be due to the discrepancy of the mechanisms of defensin induction, which may possibly be related to the diverse types/numbers of molecules involved in this process. Immunofluorescence analysis of inducible hBD2 expression by cells exposed to live A. fumigatus organisms revealed the perinuclear staining of peptide, similar to the staining observed in cells exposed to fixed A. fumigatus, pointing to the biological significance of our findings. Given the fact that conidia germinate and form hyphae after epithelial cells are exposed to live A. fumigatus conidia for 18 hours, in agreement with previous observation [44], we can then hypothesize that defensin expression is possibly induced by different morphotypes in this experiment.

Our observations of the induced defensin expression in the airway epithelial cells treated with Il- $1 \beta$ or TNF- $\alpha$, the cytokines that play an important role during Aspergillus infection $[45,46]$, suggest that defensin expression in infected cells may be induced by A. fumigatus organisms, as well as by the cytokines involved in the infectious process. Therefore, the regulation of defensin expression during Aspergillus infection may possibly depend on a variety of factors.

Significant decrease of defensin expression by neutralising anti-IL-1 $\beta$ antibody, added to the cells prior exposure to $\mathrm{SC}$, reflects the autocrine mechanism of defensin induction. A statistically insignificant decrease of defensin expression in the cells treated with anti-IL-1 $\beta$ antibody and exposed to RC or HF supported the hypothesis that the host immune system may distinguish and react differently towards divers Aspergillus morphotypes.

Finally, to better understand defensin synthesis, we investigated the involvement of transcriptional and post-transcriptional mechanisms in the regulation of defensin synthesis. The inducible expression of hBD2 and hBD9 by cells exposed to all morphotypes of A. fumigatus was inhibited by pre-treatment with actinomycin $\mathrm{D}$, implying that defensin genes are regulated at the transcriptional level. The inhibitory effect of cycloheximide on defensin induction substantiates the requirement for new protein synthesis, which may include cell receptors, transcription factors or proteins that enhance mRNA stability. Thus, post-transcriptional mechanisms of regulation were involved in the inducible expression of defensins as well.

\section{Conclusion}

While the direct fungicidal activity of hBD2 against $A$. fumigatus was revealed in the in vitro model [20], this is the first study, according to our knowledge, showing hBD2 and hBD9 defensin expression by host airway epithelial cells exposed to A. fumigatus. Defensin expression was higher in the cells exposed to SC than to RC or HF. Moreover, the HBD2 level was elevated in the supernatants of cells exposed to SC, compared to other Aspergillus morphotypes. Our findings suggest that identification of the most invasive fungal form by the host may be beneficial for anti-fungal host response.

Autocrine regulation of defensin expression in cells exposed to A. fumigatus was established in the experiments with neutralising anti-Il-1 $\beta$ antibody. Investigation of defensin expression at transcriptional and post-transcriptional level demonstrated the requirement of transcription as well as new protein synthesis during $A$. fumigatus defensin induction. The presence of defensin peptide hBD2 was revealed using immunofluorescence that showed a punctual cytoplasmic and perinuclear staining, suggestive of endoplasmic reticulum and Golgi apparatus localisation. The discovery of inducible hBD2 and hBD9 defensin expression by human primary respiratory culture cells is indicative of the biological significance of the observation. Our finding provides evidence that respiratory epithelium might play an important role in the early immune response during Aspergillus infection. Taking the antimicrobial activity of defensins together with their capacity to induce the migration of cells involved in the immune response into account, we can hypothesize that defensins may link innate and acquired immunities of the host infected by A. fumigatus. Future study of the regulation of defensin expression might provide new approaches that may enhance expression of antimicrobial peptides for potential therapeutic use during aspergillosis treatment. 


\section{Methods \\ Reagents}

Human serum, actinomycin D and cycloheximide were obtained from Sigma. Actinomycin D and cycloheximide were dissolved in dimethyl sulfoxide (DMSO) (Sigma). In all the experiments, the concentration of DMSO was always less than $0.1 \%$ (vol/vol). Interleukun-1 $\beta$ (Il-1 $\beta$ ) was purchased from Sigma. Lyophilised powder of Il-1 $\beta$ was reconstituted to the stock concentration of $10 \mu \mathrm{g} / \mathrm{ml}$ with sterile phosphate buffered saline (GIBCO BRL). Twenty $\mathrm{ng} / \mathrm{ml}$ of IL-1 $\beta$ solution was used as a positive control for defensin expression in all experiments. Monoclonal anti human Il-1 $\beta$ antibody (I3642) were obtained from Sigma. Recombinant human Tumor Necrosis Factor alpha (TNF- $\alpha$ ) was obtained from Sigma; $10 \mathrm{ng} / \mathrm{ml}$ of TNF solution was used in the experiments.

Anti-hBD-2 polyclonal antibody was purchased from Peptide International, Inc (Louisville, Kentucky, USA). Lyophilised powder of anti-hBD-2 antibody was reconstituted to the stock concentration of $10 \mathrm{mg} / \mathrm{ml}$ with sterile phosphate buffered saline (GIBCO BRL). Bronchial epithelium medium (BEGM) was obtained from Lonza Group Ltd (Basel, Switzerland).

\section{Maintenance of endotoxin-free conditions}

Experiments were designed to minimise endotoxin contamination by using purchased endotoxin-free plasticware and heating all glassware at $180^{\circ} \mathrm{C}$ for 4 hours. All solutions used in the experiments contained less then 0.007 endotoxin unit/ml (minimal detectable level) when tested with Limulus amebocyte lysate assay (Sigma). A. fumigatus organisms were washed in the solution containing Polymixin B during preparation.

\section{Patient material}

Human nasal turbinates of patients undergoing turbinectomy (Pr. G. Lamas, La Pitié-Salpêtrière University Hospital Centre, Paris, France) were used for the preparation of the primary epithelial cells. All patients signed an informed consent form before participating in this research protocol, which was approved by the Institutional Ethics Committee.

\section{Fungal strain and growth conditions}

The A. fumigatus strain, CBS 144.89 (Institut Pasteur, Paris, France), was used throughout this study. A. fumigatus conidia were prepared as previously described [22]. Briefly, conidia of A. fumigatus were obtained from cultures grown on YM agar $(0.3 \%$ yeast extract, $2 \%$ malt extract, $0.5 \%$ peptone and $0.5 \%$ agar) for three days at $37^{\circ} \mathrm{C}$. Conidia were harvested by flooding the plates with sterile distilled water and then suspending the hydrophobic conidia in $0.01 \%$ Tween 20 in phosphate-buffered solution (PBS). To remove hyphae and debris, the conid- ial suspension was filtered through four levels of gauze. The RC obtained were maintained at $4{ }^{\circ} \mathrm{C}$.

\section{Preparation of swollen conidia and hyphal fragments}

SC were prepared as described [47]. Briefly, $5 \times 10^{9}$ of resting A. fumigatus conidia were incubated in $200 \mathrm{ml}$ of Sabouraud medium for 5 hours at $37^{\circ} \mathrm{C}$ in order to obtain the isodiametric swelling of the conidium resulting in the development of SC. As demonstrated by microscopic examination, the majority of the organisms were single conidia, with a few small clumps containing two to four organisms. To obtain a homogeneous preparation, the suspension was gently sonicated for 10 seconds using a Branson Sonifier 450 (output level 2; Branson Ultrasonics, Danbury, CT, USA). Before exposure of the cells to conidia, the solution was vigorously vortexed and observed microscopically to ensure the absence of clumps.

Hyphal fragments (HF) were prepared by incubating $2 \times$ $10^{8}$ of resting conidium in $200 \mathrm{ml}$ of Sabouraud medium for 18 hours at $37^{\circ} \mathrm{C}$ with shaking in order to obtain a homogenous solution of the small HF. The tubes were then centrifuged in order to spin down the pellet. For the purpose of standardising the hyphal inoculum by weight, the pellet, which almost exclusively contained mycelium, was washed twice with Hanks balanced saline solution without $\mathrm{Ca} 2+$ and $\mathrm{Mg} 2+$ (HBSS w/o), followed by filtration through the gauze that was weighed beforehand. The gauze containing $\mathrm{HF}$ was dehydrated at $60^{\circ} \mathrm{C}$ overnight and weighed [29]. The difference between the weight of the gauze alone and the gauze containing the dry mycelium corresponds to the weight of the dry mycelium. 700 mg of dry weight of mycelial mass was obtained during experiments under the conditions described above. Twenty ml of PBS were then added to the dry mycelial mass and vigorously resuspended. All A. fumigatus morphotypes were prepared so as to minimise endotoxin contamination as described [27]. To eliminate potential endotoxin contamination, RC, SC or HF were washed in PBS containing $50 \mu \mathrm{g} / \mathrm{ml}$ of Polymixin B, known for its capacity to drastically decrease endotoxin activity, followed by four additional washings in endotoxin-free PBS. Since human cells have to be exposed to the different forms of $A$. fumigatus for various periods of time (including 18 hours to allow the RC to germinate), all A. fumigatus morphotypes were fixed in ethanol. The different solutions, containing RC, SC or HF, were centrifuged and resuspended in a 70\% solution of ethanol in PBS and stored in a refrigerator for 24 hours as described in the literature [29]. After centrifugation, either conidium or HF were vigorously resuspended in PBS containing $10 \mathrm{mg}$ of RNAse A per ml (Sigma Aldrich) and incubated for $30 \mathrm{~min}$ at $37^{\circ} \mathrm{C}$ to remove intracellular RNA [29]. After several washings in PBS, the different forms of A. fumigatus were 
viewed under the microscope; homogeneous solutions containing single resting or SC were obtained. The morphology of the mycelium was not altered. After being fixed in ethanol, mycelia (700 mg of dry weight in $20 \mathrm{ml}$ of PBS) were used as a standard HF solution. In experiments with ethanol-fixed A. fumigatus organisms, the equivalent volume of the supernatant from the last washing was added to the human cells to check for the release of any toxic material as a result of the ethanol treatment. There was no induction of the defensin expression in the cell culture incubated in the presence of the supernatants from the last washing.

\section{Human cell lines and growth conditions}

A type II pneumocyte cell line A549 derived from a human lung carcinoma was obtained from the American Type Culture Collection [ATCC CCL 185 [48]] and maintained in Kaighn's modification of HAM's F12 medium supplemented with 10\% FCS (Invitrogen, Cergy Pontoise, France), pen/strep $(16 \mathrm{mg} / \mathrm{ml}$ penicillin and $100 \mathrm{mg} / \mathrm{l}$ streptomycin), $2 \mathrm{mM}$ L-glutamine and $1.5 \mathrm{~g} / \mathrm{l}$ sodium bicarbonate. The cells were grown until confluent at $37^{\circ} \mathrm{C}$ in an incubator with a humidified atmosphere of $5 \%$ CO2. Trypsin/EDTA (Invitrogen) was used to release adherent cells for subculturing when this was required.

Human bronchial epithelial SV40-transformed cells (16HBE) were kindly provided by Dr. D.C. Gruenert (Research Facility, California Pacific Medical Center, San Francisco, CA, USA). 16HBE cells were maintained in DMEM/F12 medium (Invitrogen) with 10\% FCS (Invitrogen), pen $100 \mathrm{U} / \mathrm{ml} /$ strep $100 \mu \mathrm{g} / \mathrm{ml}, 2 \mathrm{mM}$ L-glutamine (Sigma) and $1 \mathrm{Ug} / \mathrm{ml}$ de fungizone and $1.5 \mathrm{~g} / \mathrm{l}$ sodium bicarbonate (Sigma), and were grown until confluent [49].

\section{Establishment and maintenance of human airway epithelial primary culture cells}

Primary epithelial cells were obtained from human nasal turbinates (HNT) of patients undergoing turbinectomy as previously described [50]. Briefly, HNT were washed in Dulbecco's modified Eagle medium DMEM/F12 (Invitrogen) and incubated with $2 \mathrm{mg} / \mathrm{ml}$ pronase (Protease XIV; Sigma,) in DMEM/F12 supplemented with pen/strep, at $4^{\circ} \mathrm{C}$ for $16-20 \mathrm{~h}$ under slow rotary agitation ( $80 \mathrm{rpm}$.). After washing, aggregates were discarded and dissociated cells were filtered using a $30-\mu \mathrm{m}$ pore filter. The cell suspension was then plated for $2 \mathrm{~h}$ at $37^{\circ} \mathrm{C}$ on plastic dishes (Falcon) to eliminate contaminating fibroblasts. After centrifugation, the supernatant containing the epithelial cells was cultivated in a 1:1 mix (vol:vol) of bronchial epithelium medium BEGM (Lonza Ltd): DMEM/F12 supplemented with Clonetics singlequots $(5 \mu \mathrm{g} / \mathrm{mL}$ insulin, 0.5 $\mu \mathrm{g} / \mathrm{mL}$ hydrocortisone, $0.5 \mu \mathrm{g} / \mathrm{mL}$ epinephrine, $6.5 \mathrm{ng} /$ $\mathrm{mL}$ triiodothyronine, $10 \mu \mathrm{g} / \mathrm{mL}$ transferrin, $0.5 \mathrm{ng} / \mathrm{mL}$ human epidermal growth factor, $50 \mu \mathrm{g} / \mathrm{mL}$ gentamicinamphotericinB, $0.13 \mathrm{mg} / \mathrm{mL}$ bovine pituitary extract), 50 $\mathrm{U} / \mathrm{mL}$ of penicillin-streptomycin and $0.5 \%$ fungizone.

\section{Heat inactivation of the serum}

In the experiments devoted to the investigation of the role of the heat-labile component of serum in the production of defensins by the human airway epithelium, heat inactivation of the serum, the recognised method for serum decomplementation, was performed as described [51]. Briefly, either human autologous serum or heterologous FCS was heated at $56^{\circ} \mathrm{C}$ for $30 \mathrm{~min}$. After cultivation of the human respiratory cells under the conditions described above, the cells were exposed to A. fumigatus in the medium containing serum that was either heat-inactivated or not.

\section{Exposure of the cells to A. fumigatus conidia or hyphal fragments}

$5 \times 10^{6}$ of A549, $16 \mathrm{HBE}$ or primary culture cells were placed in six well plates in $1.5 \mathrm{ml}$ of the corresponding medium described above and grown until confluence. Following washing of A549, 16HBE or primary culture cells with PBS, $10^{6}$ of A. fumigatus conidia per millilitre of medium were added to the cells for 4, 8 or 18 hours. Exposure to HF was carried out by incubation of the cells for 4 , 8 or 18 hours with $20 \mu \mathrm{l}$ of the standard solution $(35 \mathrm{mg}$ of dry weight $/ \mathrm{ml}$ ) obtained from $2 \times 10^{8}$ of resting conidium as described above. All A. fumigatus morphotypes were washed an additional four times in endotoxin-free PBS prior to use to eliminate potential endotoxin contamination.

After incubation, unbound conidia were removed by washing wells with PBS prior to RNA purification.

Primary epithelial cells were seeded at $5 \times 10^{6}$ cells per well and grown for $48 \mathrm{~h}$ before exposure to A. fumigatus.

In some experiments, the cells were exposed to $10^{6}$ unfixed live conidia for 18 hours.

To be sure that the inducible expression of defensins was specific to A. fumigatus and did not simply reflect a phagocytosis response, latex beads were used as a control, since it was shown that the respiratory cells are capable of internalising nonspecific particles such as latex beads [52]. Compared to the concentration of conidia, up to a fivefold higher concentration of latex beads was used in the experiments, as suggested [30].

Before exposing the cells to the A. fumigatus organisms, the solutions were vigorously vortexed and observed microscopically to ensure that they did not contain clumps. 


\section{RNA isolation and analysis of defensin expression by RT- PCR}

In order to ensure that the cells were exposed to different morphotypes of A. fumigatus organisms (conidia or HF) during the incubation period, the cell culture was observed microscopically at the beginning and at the end of the exposure. The medium was discarded, the wells were briefly washed with PBS solution, and TRIzol reagent was added to the cells.

Total RNA was isolated with TRIzol Reagent (Invitrogen, Cat N 15596-026) according to the manufacturer's instructions. RNA was precipitated with ethanol and resuspended in diethyl pyrocarbonate $\mathrm{H}_{2} \mathrm{O}$. The RNA concentration was measured by spectroscopy, and the integrity of RNA was assessed on an agarose gel. cDNA was synthesized from $1 \mu \mathrm{g}$ of purified RNA, using $50 \mathrm{nM}$ of Oligo dT, 16 mer, (Operon Biotechnologies SP230), 30 units of AMV Reverse Transcriptase (Promega M5108) and RNA-se free $\mathrm{H}_{2} \mathrm{O}$ in a reaction volume of $25 \mu \mathrm{l}$, according to the manufacturer's recommendations. Identical reactions devoid of reverse transcriptase (-RT) were carried out in parallel and did not lead to any DNA amplification of predicted molecular weight in contrast to reverse transcriptase-containing reactions. Reactions containing $\mathrm{H}_{2} \mathrm{O}$ instead of cDNA were also used in negative controls (data not shown).

A RT-PCR approach was used for the analysis of defensin expression in A549 and 16HBE human respiratory cell lines, as well as in primary culture of human respiratory cells exposed to RC, SC, or HF. Gene-specific primers for hBD1 and hBD2 were designed according to the sequences available at the National Center for Biotechnology Information http://www.ncbi.nlm.nih.gov/ in order to amplify specific cDNA sequences and avoid genomic DNA amplification. In this respect, primer sequences were designed to cover at least two subsequent exons, the human beta-defensin (HBD) -1 and -2 (NCBI accession \# NM 005218.3 and NM 004942.2, respectively). It should be observed that hBD2 is now referred to as hBD-4 in the NCBI database. However, we decided to use the term, $\mathrm{hBD} 2$, since it is widely used in scientific literature today [53]. For the analysis of hBD8, hBD9 and hBD18, we relied on previous studies; the primers and PCR conditions were used as described in [10].

The PCR-amplified cDNA band of glyceraldehyde-3-phosphate dehydrogenase (GAPDH, NCBI accession \# NM 2046.3) was used as an internal control with the predicted size of $473 \mathrm{bp}$. In each reaction, the initial denaturing step was $94^{\circ} \mathrm{C}$ for $8 \mathrm{~min}$, followed by 32-38 cycles [denaturation at $94^{\circ} \mathrm{C}$ for 40 seconds, annealing at $56-61^{\circ} \mathrm{C}$ (according to primer melting temperature) for $40 \mathrm{~s}$ and elongation at $72^{\circ} \mathrm{C}$ for 1 minute]. The final elongation step was $72^{\circ} \mathrm{C}$ for $7 \mathrm{~min}$. The primer annealing temperatures, cycles and predicted PCR product sizes for the transcripts investigated are summarised in Table 1. The PCRamplified cDNA products were separated by electrophoresis on a $2 \%$ agarose gel and visualised by ethidium bromide after staining. The forward primers ( $\mathrm{f}$ ) and reverse primers (r) used are presented in Table 1. Identification of each defensin was confirmed by direct sequencing of respective PCR products, using upstream PCR primers (DNA Sequencing Facility, Qiagen, France).

\section{Quantitative Real Time PCR}

The level of mRNA for HBD2, HBD9 and GAPDH in human cells was quantified using real time PCR analysis. Three different experiments were performed. Isolation of total RNA with TRIzol Reagent and synthesis of cDNA was performed as described above. To perform real time PCR, gene-specific primers were designed according to the sequences available at the National Center for Biotechnology Information http://www.ncbi.nlm.nih.gov/, using Beacon Designer 2 software (Table 2).

In order to amplify specific cDNA sequences and to avoid genomic DNA amplification, all primer sequences were designed to cover at least two subsequent exons (Table 2). Relative quantification relates the PCR signal of the target transcript in a treatment group to that of an untreated control. For each primer-pair, the amplification efficiency was determined by serial dilution experiments and the resulting efficiency coefficient was used for quantification of the products [54]. Each $25 \mu \mathrm{l}$ Quantitative PCR mixture included 5 microl of DNA, $0.08 \mu \mathrm{l}$ of primers $(300 \mathrm{nM})$, $12.5 \mu \mathrm{l}$ of CYBR green IQ supermix $(2 \times)$ (ABgene) and $\mathrm{H} 2 \mathrm{O}$. Quantitative PCR amplification was carried out on an iCycler iQ system (Bio-Rad, Marne la Coquette, France) with the following parameters: $15 \mathrm{~min}$ at $95^{\circ} \mathrm{C}$ and 40 cycles of two steps consisting of $30 \mathrm{~s}$ at $95^{\circ} \mathrm{C}, 30 \mathrm{~s}$ at $55^{\circ} \mathrm{C}$. The relative quantification of the mRNA levels of the target genes was determined using the deltaCT method [55]. Briefly, the amount of target was normalised to the endogenous reference gene GAPDH: deltaCT $=\mathrm{CT}$ (target gene) - CT (GAPDH) where CT represents the cycle number required to reach a defined threshold target abundance. The relative mRNA level was calculated as $\times$ del-

Table 2: Primer sequences and annealing temperatures (Real Time PCR)

\begin{tabular}{lll}
\hline Primers & Sequences & Conditions \\
\hline hBD2f & 5'-tatctcctcttctcgttcctcttc-3' & 40 cycles, $55^{\circ} \mathrm{C}$, \\
hBD2r & $5^{\prime}$-ccacaggtgccaatttgtttatac-3' & $2.5 \%$ DMSO \\
hBD9f & 5 '-ggcctaaatccaggtgtgaa-3' & 40 cycles, $55^{\circ} \mathrm{C}$ \\
hBD9r & $5^{\text {'-tcaaatgttggcaagtggag-3' }}$ & \\
GAPDHf & $5^{\prime}$-acccactcctccacctttgac-3' & 40 cycles, $55^{\circ} \mathrm{C}$ \\
GAPDHr & 5'-tccaccaccctgttgctgtag-3' & \\
& & \\
\hline
\end{tabular}


taCT ( $\mathrm{x}=$ Primer efficiency) (Pfaffl, 2001). All reactions were performed in triplicate and included a negative (-RT) control without reverse transcriptase.

\section{Neutralising anti-IL-I antibody}

Experiments designed to analyse the role of IL-1 $\beta$ in $A$. fumigatus-induced defensin expression were performed using real time PCR. $5 \times 10^{6}$ of A549 or $16 \mathrm{HBE}$ cells were placed in six well plates in $1.5 \mathrm{ml}$ of the corresponding medium and grown until confluence. The cells were divided into three groups. The cells of the first group were exposed to either $A$. fumigatus morphotypes or beads for 18 hours as described above. Neutralising anti-IL- $1 \beta$ antibody $(10 \mu \mathrm{g} / \mathrm{ml})$ was added to the cells of the second group prior exposure to A. fumigatus organisms or beads for the same period. The amount of neutralising antibody was equal to that used in the experiments devoted to the study of the role of Il-1 $\beta$ synthesized by the monocytes infected with Streptococci [56]. Normal mouse immunoglobulin $(10 \mu \mathrm{g} / \mathrm{ml})$ was used instead of neutralising antibody for the third group of cells. After collection of cells, RNA were isolated using TRIzol reagent and real time PCR was performed as described above.

\section{Immunofluorescence}

Either A549 or $16 \mathrm{HBE}$ cells were seeded at $5 \times 10^{5}$ cells per well in $1 \mathrm{ml}$ of DMEM/F12 on 18-mm-diameter cover slips (Marienfeld, Germany) in 12 well plates (Nunc, NuclonTM Surface) in triplicate and grown for $16 \mathrm{~h}$ at $37^{\circ} \mathrm{C}$. After washing the cover slips with $5 \%$ BSA/PBS (BSA, Fraction V, Sigma), the cells were exposed to either $10^{6}$ fixed conidia or to $20 \mu \mathrm{l}$ of the fixed HF solution (20 $\mathrm{mg}$ of dry weight $/ \mathrm{ml}$ ), or $5 \times 10^{6}$ latex beads for 24 hours. The untreated cell culture was used as a negative control. The treatment with 20 ng of Il- $1 \beta$, a well-known inductor of defensins [57], was used as a positive control. In some experiments, the cells were treated with $10 \mathrm{ng} / \mathrm{ml}$ of TNF$\alpha$. The cells were then fixed with freshly prepared $4 \%$ solution of paraformaldehyde for $30 \mathrm{~min}$ at $37^{\circ} \mathrm{C}$, followed by permeabilisation in $0.05 \%$ of Triton/PBS solution. The slides were then incubated in 5\% BSA/PBS, and then in a solution of $10 \%$ normal goat serum (Sigma). After washing, rabbit anti-human hBD2 (Peptide Institute 234) at a dilution of 1:250 was applied as a primary antibody overnight at $4{ }^{\circ} \mathrm{C}$, followed by incubation with FITC-labelled goat anti-rabbit secondary antibody (Sigma, Ac35-FITC) at a dilution of 1:300 for 4 hours at room temperature [58]. After washing, the cover slips were mounted on slides with ProLong antifade Vectashield (Vectashield, Biovalley). Samples were viewed with a Zeiss fluorescence microscope using $\times 400$ magnification. For each sample, cells from five random fields were counted and the percentage of the cells stained with anti-defensin- 2 antibody was calculated as the number of stained cells divided by the total number counted, multiplied by 100 . The epithe- lial cells incubated with normal rabbit serum at a dilution of $1: 250$ (Sigma, $10 \mathrm{mg} / \mathrm{ml}$ ) as a negative control showed no reactivity.

\section{Analysis of co-localisation of intracellular hBD-2 and A.} fumigatus conidia or hyphal fragments

Co-localisation experiments were performed according to the method described by Botterel at al. with modifications [32]. After exposing the cells to $10^{6}$ per millilitre of medium of RC, SC or $20 \mu \mathrm{l}$ of the standard HF solution (35 mg of dry weight $/ \mathrm{ml}$ ) for 18 hours, the cells were fixed and permeabilised as indicated above. The cells were then labelled with primary rabbit anti-hBD2 antibody (Peptide Institute 234) at a dilution of 1:250 overnight at $4{ }^{\circ} \mathrm{C}$, followed by incubation with Tex Red-labelled goat anti-rabbit secondary antibody (Sigma) at a dilution of 1:300 for 1 hour at $37^{\circ} \mathrm{C}$. After washing in PBS, the cover slips were mounted on slides with ProLong antifade Vectashield (Vectashield, Biovalley, USA). Samples were viewed with a Zeiss fluorescence microscope using $\times 400$ magnification and the images were compared to the phase-contrast images in order to identify stained internalised A. fumigatus organisms.

\section{Detection of hBD2 in cell supernatants}

Analysis of the hBD2 in cell supernatants was performed by sandwich-ELISA. Either A549 or 16HBE cells were seeded at $10^{6}$ cells per well in $1 \mathrm{ml}$ of DMEM/F12 in 12 well plates in triplicate and grown for $24 \mathrm{~h}$ at $37^{\circ} \mathrm{C}$. Primary culture HNT cells were grown for 48 hours in BEGM medium as described above. The cells were then exposed to $10^{6}$ per millilitre of medium of RC, SC or $20 \mu \mathrm{l}$ of the standard HF solution ( $35 \mathrm{mg}$ of dry weight $/ \mathrm{ml}$ ) for 18 hours. Cell supernatants were then centrifuged at $9000 \mathrm{~g}$ for $10 \mathrm{~min}$ at $4^{\circ} \mathrm{C}$ and analysed for the presence of hBD2 with a commercial ELISA kit (Antigenix America, Inc., NY, USA) according to the manufacturer's instructions. Briefly, a 96-well ELISA plate (Nunc, NY, USA) was coated with $100 \mu \mathrm{l}$ of $0.5 \mu \mathrm{g} / \mathrm{ml}$ of capture anti-hBD2 antibody. The plate was sealed and incubated overnight at room temperature. After washing with phosphate buffer solution (PBS) containing $0.05 \%$ Tween 20, non-specific binding sites of the wells were blocked with $200 \mu \mathrm{l}$ of $0.1 \%$ Bovine Serum Albumin (BSA)/PBS solution for 1 hour at room temperature. The wells were then washed again and $100 \mu \mathrm{l}$ of cell supernatants or standard recombinant hBD2 in duplicate were added to the wells for 2 hours at room temperature. Serial dilutions of standard hBD2 from $10 \mathrm{ng} / \mathrm{ml}$ to $0.01 \mathrm{ng} / \mathrm{ml}$ were performed in diluent containing 0.1 BSA in $0.05 \%$ Tween 20/PBS. After washing, $100 \mu \mathrm{l}$ of tracer biotinilated antibody was added to the wells at a concentration of $0.25 \mu \mathrm{g} / \mathrm{ml}$ for 2 hours at room temperature. The wells were then washed again and streptavidin-horse radish peroxidise solution at a concentration of $1 \mu \mathrm{g} / \mathrm{ml}$ was added for 30 minutes at room 
temperature, followed by intensive washing. Liquid chromogenic substrate (3, 3', 5, 5'-Tetramethyl-Benzidine) solution was used for colour development. The ELISA plate was read using a 96-well plate reader IEMS, THERMO LABSYSTEMS (Thermo Fisher Scientific, CergyPontoise, France) at $450 \mathrm{~nm}$ (correction set at $650 \mathrm{~nm}$ ) with 5 min intervals for 20 minutes. The sensitivity of ELISA for hBD2 was $10 \mathrm{pg} / \mathrm{ml}$.

\section{Analysis of defensin expression by cells treated with inhibitors of protein synthesis and gene transcription}

To examine the mechanism(s) for inducible defensin expression in response to A. fumigatus, human airway epithelial cells A549 or $16 \mathrm{HBE}$ were pre-treated with either $2.5 \mu \mathrm{g}$ of cycloheximide (an inhibitor of protein synthesis) per ml, $0.5 \mu \mathrm{g}$ of actinomycin D (an inhibitor of RNA transcription) per ml, or DMSO (vehicle control), $1 \mathrm{~h}$ before exposure to A. fumigatus for an additional 6 or 18 hours. In this study, we used lower doses of actinomycin $\mathrm{D}$ and cycloheximide than were previously described [33], in order to avoid their toxic effect during incubation of the cells for 18 hours. The viability of human cells as assessed by trypan blue and total RNA yield were checked after each treatment, and no differences were found between experimental and untreated control cells.

\section{Statistical analysis}

The differences in the percentage of the cells positively stained with anti-defensin antibody in the cell cultures exposed or not to A. fumigatus were assessed by analysis of variance. P-values $<0.05$ were considered to be significant. Tukey's honestly significant difference test was applied for comparison of means between groups. The values are expressed as mean \pm SEM. At least three different assays were performed per experiment

\section{Authors' contributions}

LA, DH, NB and IM carried out PCR experiments, FF was responsible for cell growth, and FF and NB performed immunofluorescence experiments. DH was in charge of the preparation of A. fumigatus organisms. FF, MA and AC performed the experiments with live A. fumigatus. VTS and ABS were involved in primary culture cell growth. DG designed some of the primers, RC participated in the preparation of $A$. fumigatus mycelium and DH and NB carried out ELISA experiments. JPL participated in the design of some of the experiments. NB was responsible for the conception and design of the study, analysis and interpretation of the data, statistical analysis and for the writing of the manuscript. JPL and NB were responsible for revising the manuscript for intellectual content and gave the final approval of the version to be submitted. All authors read and approved the final version of the manuscript.

\section{Acknowledgements}

This work was supported by a grant from INRA (French National Institute of Agricultural Research), a bi-lateral collaboration. Ludmila Alekseeva was a recipient of a post-doctoral fellowship from MRI INRA. Mahdia Abdeluahab was the recipient of a fellowship from the Animal Health Department of INRA. We are grateful to Dr. S. Dutertre, the head of the microscopy platform of the Institut Fédératif de Recherche 140, Rennes, France, for assistance in immunostaining analysis. We gratefully acknowledge Pr. G. Lamas (La Pitié-Salpêtrière University Hospital Centre, Paris, France) for his help in the preparation of patient material. We would also like to thank Dr. Tom Ganz (Department of Medicine at the Will Rogers Institute for Pulmonary Research, University of California School of Medicine, Los Angeles, CA, USA) for his helpful suggestions for the experiments and the critical reading of the manuscript. We are grateful to Mr. Bernard Charpentier and Ms. Aline Jeannel (MRI, INRA, Paris) for their assistance in the organisation of this work. We thank Gail Wagman for revising the English.

\section{References}

I. Denning DW, Anderson MJ, Turner G, Latgé JP, Bennett JW: Sequencing the Aspergillus fumigatus genome. Lancet Infect $D$ is 2002, 2(4):25I-253.

2. Kleinberg M: Aspergillosis in the CLEAR outcomes trial: working toward a real-world clinical perspective. Med Mycol 2005, 43(SuppI I):289-294.

3. Bals R: Epithelial antimicrobial peptides in host defense against infection. Respir Res 2000, I:I4I-150.

4. Ganz T, Weiss T: Antimicrobial peptides of phagocytes and epithelia. Semin Hematol 1997, 34(4):343-354.

5. Cunliffe RN, Mahida YR: Expression and regulation of antimicrobial peptides in the gastrointestinal tract. J Leukocyte Biol 2004, 75:49-58.

6. Tang Y-Q, Yaun J, Osapay G, Osapay C, Tran D, Miller C, Quellette $A$, Selsted $M$ : $\mathbf{A}$ cyclic antimicrobial peptide produced in primateleukocytes by the ligation of two truncated a-defensins. Science 1999, 286:498-502.

7. García JR, Jaumann F, Schulz S, Krause A, Rodríguez-Jiménez J, Forssmann U, Adermann K, Klüver E, Vogelmeier C, Becker D, Hedrich R, Forssmann WG, Bals : Identification of a novel, multifunctional beta-defensin (human beta-defensin 3 ) with specific antimicrobial activity. Its interaction with plasma membranes of Xenopus oocytes and the induction of macrophage chemoattraction. Cell Tissue Res 200I, 306(2):257-264.

8. Jia HP, Schutte BC, Schudy A, Linzmeier R, Guthmiller JM, Johnson GK, Tack BF, Mitros JP, Rosenthal A, Ganz T, McCray PB: Discovery of new human beta-defensins using a genomics-based approach. Gene 200I, 263(I-2):2II-2I8.

9. Schutte BC, Mitros JP, Bartlett JA, Walters JD, Jia HP, Welsh MJ, Casavant TLPB Jr, McCray TL: Discovery of five conserved betadefensin gene clusters using a computational search strategy. Proc Natl Acad Sci USA 2002, 99(4):2 I 29-33.

10. Kao CY, Chen Y, Zhao YH, Wu R: ORFeome-based search of airway epithelial cell-specific novel human [beta]-defensin genes. Am J Respir Cell Mol Biol 2003, 29(I):7I-80.

II. Bensch KW, Raida M, Mägert HJ, Schulz-Knappe P, Forssmann WG: hBD-I: a novel beta-defensin from human plasma. FEBS Lett 1995, 368(2):33।-335

12. Zhao C, Wang I, Lehrer RI: Widespread expression of betadefensin hBD-I in human secretory glands and epithelial cells. FEBS Lett 2005, 396(2-3):319-322.

13. Harder J, Bartels J, Christophers E, Schröder JM: A peptide antibiotic from human skin. 1997, 387:861-867.

14. Schröder JM, Harder J: Human beta-defensin-2. Int J Biochem Cell Biol I999, 3 I (6):645-65I.

15. Weinberg A, Krisanaprakornkit S, Dale BA: Epithelial antimicrobial peptides: review and significance for oral applications. Crit Rev Oral Biol Med 1998, 9(4):399-4|4. dendritic and T cell CCR6. Science 1999, 286:525-528

16. Funderburg N, Lederman MM, Feng Z, Drage MG, Jadlowsky J, Harding CV, Weinberg A, Sieg SF: Human -defensin-3 activates professional antigen-presenting cells via Toll-like receptors I and 2. Proc Natl Acad Sci USA 2007, 104(47): | $863 \mid$ - | 8635. 
17. Soruri A, Grigat J, Forssmann U, Riggert J, Zwirner J: BetaDefensins chemoattract macrophages and mast cells but not lymphocytes and dendritic cells: CCR6 is not involved. Eur J Immunol 2007, 37(9):2474-2486.

18. Yang D, Chertov O, Bykovskaia S, Chen Q, Buffo MJ, Shogan J, Anderson M, Schröder JM, Wang JM, Howard OM, Oppenheim J]: Betadefensins: linking innate and adaptive immunity through dendritic and T cell CCR6. Science 286:525-528.

19. Levitz SM, Selsted ME, Ganz T, Lehrer RI, Diamond RD: In vitro killing of spores and hyphae of Aspergillus fumigatus and Rhizopus oryzae by rabbit neutrophil cationic peptides and bronchoalveolar macrophages. J Infect Dis 1986, I 54(3):483-489.

20. Okamoto T, Toyohiro T, Wei B, Ueta E, Yamamoto T, Osaki T: Regulation of Fungal Infection by a Combination of Amphotericin B and Peptide 2, a Lactoferrin Peptide That Activates Neutrophils. Clin Diagn Lab Immunol 2004, I I (6): I I I - I I I 9.

21. Simon A, Kullberg BJ, Tripet B, Boerman OC, Zeeuwen P, VenJongekrijg J van der, Verweij P, Schalkwijk J, Hodges R, Meer JW van der, Netea MG: Drosomycin-like defensin, a human homologue of Drosophila melanogaster drosomycin with antifungal activity. Antimicrob Agents Chemother 2008, 52(4): 1407-I4I2.

22. Berkova N, Lair-Fulleringer S, Femenia F, Huet D, Wagner MC Gorna K, Tournier F, lbrahim-Granet O, Guillot J, Chermette R, Boireau P, Latge JP: Aspergillus fumigatus conidia inhibit tumour necrosis factor- or staurosporine-induced apoptosis in epithelial cells. Intern Immunol 2006, I8: I39-150.

23. Khoufache K, Puel O, Loiseau N, Delaforge M, Rivollet D, Coste A, Cordonnier C, Escudier E, Botterel F, Bretagne S: Verruculogen associated with Aspergillus fumigatus hyphae and conidia modifies the electrophysiological properties of human nasal epithelial cells. BMC Microbiol 2007, 23:7:5-16.

24. Zhang Z, Liu R, Noordhoek JA, Kauffman HF: Interaction of airway epithelial cells (A549) with spores and mycelium of Aspergillus fumigatus. J Infect 2005, 5 I (5):375-82.

25. Bellocchio S, Bozza S, Montagnoli C, Perruccio K, Gaziano R, Pitzurra L, Romani L: Immunity to Aspergillus fumigatus: the basis for immunotherapy and vaccination. Med Mycol 2005, 43:SI8I-I 88 .

26. Steele C, Rapaka RR, Metz A, Pop SM, Williams DL, Gordon S, Kolls JK, Brown GD: The beta-glucan receptor dectin-I recognizes specific morphologies of Aspergillus fumigatus. PLoS Pathog 2005, I(4):42-48.

27. Mambula SS, Sau K, Henneke P, Golenbock DT, Levitz SM: Toll-like receptor (TLR) signaling in response to Aspergillus fumigatus. J Biol Chem 2002, 277(42):39320-39326.

28. Stark H, Roponen M, Purokivi M, Randell J, Tukiainen H, Hirvonen MR: Aspergillus fumigatus challenge increases cytokine levels in nasal lavage fluid. Inhal Toxicol 2006, 18(13): 1033-1039.

29. Wang JE, Warris A, Ellingsen EA, Jorgensen PF, Flo TH, Espevik T, Solberg R, Verweij PE, Aasen AO: Involvement of CDI4 and TollLike Receptors in Activation of Human Monocytes by Aspergillus fumigatus Hyphae. Infect Immun 200I, 69(4):2402-2406.

30. Wasylnka J, Moore M: Uptake of Aspergillus fumigatus Conidia by Phagocytic and Nonphagocytic Cells In Vitro: Quantitation Using Strains Expressing Green Fluorescent Protein. Infect Immun 2002, 70:3156-3163.

31. Wasylnka JA, Moore MM: Aspergillus fumigatus conidia survive and germinate in acidic organelles of A549 epithelial cells. Cell Sci 2003, I I 6(8): I579-I587.

32. Botterel F, Gross K, Ibrahim-Granet O, Khoufache K, Escabasse V, Coste A, Cordonnier C, Escudier E, Bretagne S: Phagocytosis of Aspergillus fumigatus conidia by primary nasal epithelial cells in vitro. BMC Microbiol 2008, 18;8:97-106.

33. Krisanaprakornkit S, Kimball JR, Weinberg A, Darveau RP, Bainbridge BW, Dale BA: Inducible expression of human beta-defensin 2 by Fusobacterium nucleatum in oral epithelial cells: multiple signaling pathways and role of commensal bacteria in innate immunity and the epithelial barrier. Infect Immun 2000, 68(5):2907-2915.

34. Singh PK, Jia HP, Wiles K, Hesselberth J, Liu L, Conway BA, Greendberg EP, Valore EV, Welsh MJ, Ganz T, Tack BF, McGray PB Jr: Production of beta-defensins by human airway epithelia. Proc Natl Acad Sci USA 1998, 95(25): | 496|-| 4966

35. Rivas-Santiago B, Schwander SK, Sarabia K, Diamond G, Klein-Patel ME, Hernandez-Pando R, Ellner J, Sada E: Human $\beta$-defensin $\mathbf{2}$ is expressed and associated with Mycobacterium tuberculosis during infection of human alveolar epithelial cells. Infect Immun 2005, 73:4505-45II.

36. Premratanachai P, Joly S, Johnson GK, McCray PB, Jia HP, Guthmiller IM: Expression and regulation of novel human beta-defensins in gingival keratinocytes. Oral Microbiol Immunol 2004, 19(2): I II-II7.

37. Bhat S, Song YH, Lawyer C, Milner S: Modulation of the Complement System by Human $\beta$-Defensin 2. J Burns Wounds 2007, 5:el0.

38. Perlmutter $\mathrm{DH}$, Colten HR: The role of complement in the pathophysiology of lung diseases. In The lung 2nd edition. Edited by: Crystal RG, West JB. Philadelphia: Lippincott-Raven; 1997:84I-57.

39. Varsano S, Kaminsky M, Kaiser M, Rashkovsky L: Generation of complement $\mathrm{C} 3$ and expression of cell membrane complement inhibitory proteins by human bronchial epithelium cell line. Thorax 2000, 55:364-369.

40. Gersuk GM, Underhill DM, Zhu L, Marr KA: Dectin-I and TL Rs permit macrophages to distinguish between different Aspergillus fumigatus cellular states. J Immunol 2006, I 76(6):37| 7-3724

4I. Daher KA, Lehrer RI, Ganz T, Kronenberg M: Isolation and characterization of human defensin cDNA clones. Proc Natl Acad Sci USA 1988, 85:7327-7332

42. Rahman A, Fahlgren A, Sitohy B, Baranov V, Zirakzadeh A, Hammarström S, Danielsson A, Hammarström ML: Beta-defensin production by human colonic plasma cells: a new look at plasma cells in ulcerative colitis. Inflamm Bowel Dis 2007, I3(7):847-855.

43. Rizzo A, Paolillo R, Buommino E, Lanza AG, Guida L, Annunziata M, Carratelli CR: Modulation of cytokine and beta-defensin 2 expressions in human gingival fibroblasts infected with Chlamydia pneumoniae. Int Immunopharmacol 2008, 8(9):1239-1247.

44. Lopes Bezerra L, Filler S: Interactions of Aspergillus fumigatus with endothelial cells:internalization, injury, and stimulation of tissue factor activity. Blood 2004, 103:2। 43-2149.

45. Mehrad B, Strieter RM, Standiford TJ: Role of TNF-alpha in pulmonary host defense in murine invasive aspergillosis. J Immunol 1999, 162:1633-40.

46. Netea MG, Warris A, Meer JW Van der, Fenton MJ, Verver-Janssen TJ, Jacobs LE, Andresen T, Verweij PE, Kullberg BJ: Aspergillus fumigatus evades immune recognition during germination through loss of toll-like receptor-4-mediated signal transduction. J Infect Dis 2003, 188:320-6.

47. Behnsen J, Hartmann A, Schmaler J, Gehrke A, Brakhage A, Zipfel PF: The opportunistic human pathogenic fungus Aspergillus fumigatus evades the host complement system. Infect Immun 2008, 76(2):820-827.

48. Lieber M, Smith B, Szakal A, Nelson-Rees W, Todaro S: A continuous tumor-cell line from a human lung carcinoma with properties of type II alveolar epithelial cells. Int J Cancer 1976, 17:62-67.

49. Cozens AL, Yezzi MJ, Kunzelmann K, Ohrui T, Chin L, Eng K, Finkbeiner WE, Widdicombe JH, Gruenert DC: CFTR expression and chloride secretion in polarized immortal human bronchial epithelial cells. Am J Respir Cell Mol Biol 1994, I0(I):38-47.

50. Million K, Tournier F, Houcine O, Ancian P, Reichert U, Marano F: Effects of retinoic acid receptor-selective agonists on human nasal epithelial cell differentiation. Am J Respir Cell Mol Biol 2002. 25(6):744-750.

5I. Morigi M, Zoja C, Colleoni S, Angioletti S, Imberti B, Donadelli R, Remizzi A: Xenogeneic Serum Promotes Leukocyte-Endothelium Interaction under Flow through Two Temporally Distinct Pathways: role of complement and nuclear factorkappaB. J Am Soc Nephrol 1999, 10:21 197-2203.

52. Griese M, Reinhardt D: Smaller sized particles are preferentially taken up by alveolar type II pneumocytes. J Drug Target 1998, 5:47I-479.

53. Krisanaprakornkit $S$, Chotjumlong $P$, Kongtawelert $P$, Reutrakul V: Involvement of phospholipase $D$ in regulating expression of anti-microbial peptide human beta-defensin-2. Int Immunol 2008, 20(I):2I-29.

54. Pfaffl MW: A new mathematical model for relative quantification in real-time RT-PCR. Nucleic Acids Res 200I, 29(9):e45.

55. Livak KJ, Schmittgen TD: Analysis of relative gene expression data using real-time quantitative PCR and the 2(-Delta Delta C(T)). Methods 200I, 25:402-408. 
56. Hahn CL, Best AM, Tew JG: Rapid tissue factor induction by oral streptococci and monocyte-IL-Ibeta. J Dent Res 2007, 86(3):255-259.

57. Jang BC, Lim KJ, Choi IH, Suh MH, Park JG, Mun KC, Bae JH, Shin DH, Suh SI: Triptolide suppresses interleukin-I beta-induced human beta-defensin- 2 mRNA expression through inhibition of transcriptional activation of NF-kappaB in A549 cells. Int J Mol Med 2007, 19(5):757-763.

58. Sugawara $Y$, Uehara A, Fujimoto $Y$, Kusumoto $S$, Fukase $K$, Shibata $K$, Sugawara S, Sasano T, Takada H: Toll-like Receptors, NODI, and NOD2 in Oral Epithelial Cells. J Dent Res 2006, 85(6):524-529.

Publish with Bio Med Central and every scientist can read your work free of charge

"BioMed Central will be the most significant development for disseminating the results of biomedical research in our lifetime. "

Sir Paul Nurse, Cancer Research UK

Your research papers will be:

- available free of charge to the entire biomedical community

- peer reviewed and published immediately upon acceptance

- cited in PubMed and archived on PubMed Central

- yours - you keep the copyright

Submit your manuscript here:

http://www.biomedcentral.com/info/publishing_adv.asp
BioMedcentral 